\title{
Article 13 (b) vs Principle of Legality
}

The crimes of genocide, crimes against humanity, war crimes and aggression have all been crimes within the jurisdiction of at least one of the other international criminal tribunals and courts established prior to the ICc. ${ }^{1}$ However, their precise definition as contained in the Rome Statute is in some important respects novel. ${ }^{2}$ Despite the averred intention of the Rome Statute's drafters to follow customary international law, "drafting the Statute required clarifying and elucidating the precise content of offenses in a way that often moved the 'law' of the Statute far beyond existing customary international law understandings." 3

Article 10 evidences this possibility of a discrepancy between the substantive criminal provisions of the Statute and customary international law. ${ }^{4}$ It has been said that Article 22 (3) further "prevents any misconceptions that might arise as to whether the Statute exclusively codifies or exhausts international criminal prohibitions. ${ }^{5}$ As the ICTY stated in Prosecutor v. Furundzija, "[d]epending on the matter at issue, the Rome Statute may be taken to restate, reflect or clarify customary rules or crystallise them, whereas in some areas it creates new law or modifies existing law." ${ }^{6}$ An example of where the Statute creates new law might be, as maintained in Cassese's International Criminal Law edited in 2013, Article 7 (2) (i) Rome Statute. ${ }^{7}$ According to the authors, the Statute's provision on enforced disappearance of persons as a crime against humanity "has not codified customary international law but contributed to the crystallization of a nascent rule". ${ }^{8}$ With the wide ratification of the Rome Statute and its open intent to be universally ratified it is not out of question

1 See Nuremberg Charter, Art. 7; Tokyo Charter, Art. 5; ICTY Statute, Art. 2,3, 4 and 5; ICTR Statute, Art. 2,3 and 4; SCSL Statute, Art. 2, 3, and 4.

2 Schabas, An Introduction, 90.

3 Sadat, Transformation of International Law, 12.

4 Rome Statute, Art. 10; See also Sadat, "Article 10 of the ICC Statute," 909.

5 Broomhall, "Article 22," 719; Lamb, "Nullum Crimen," 754.

6 Prosecutor v. Furundzija, Case No. IT-95-17/1-T, Judgment (Dec. 10, 1998), par. 227; Prosecutor v. Tadic, Case No. IT-94-1-A, Judgment (Jul. 15, 1999), par. 223.

7 Cassese et al., Cassese's International Criminal Law, 98; See also Introduction, fn 26 and Grover, Interpreting Crimes, 341-343 for other crimes that might not yet be established under customary international law.

8 Cassese et al., Cassese's International Criminal Law, 98. 
that all the Statute's criminal provisions may be reflective of customary international law in the near future. ${ }^{9}$ However, several important States from different geographical regions still need to ratify the Statute. Furthermore, the Statute has already been amended three times to adopt a definition of aggression and include some new war crimes within the jurisdiction of the Court. ${ }^{10}$ Except for the first amendment to Article 8 - which criminalizes the use of poisoned weapons, asphyxiating gases, and expanding or flattening bullets in non-international armed conflicts - there is no consensus on whether the other amendments reflect customary international law. ${ }^{11}$ Thus, a discrepancy between the Statute and customary international law remains a legal issue that is particularly problematic when the ICC exercises retroactive jurisdiction over individuals for crimes under the Rome Statute while they were neither nationals nor had been acting in the territories of States party to the Statute at the time of the conduct in question.

While a clash between retroactive referrals and non-retroactivity of criminal prohibition can also arise in situations where the ICC exercises retroactive jurisdiction on the basis of an Article 12 (3) declaration of acceptance, ${ }^{12}$ this chapter focuses on referrals under Article 13 (b) of the Rome Statute. Referrals under Article 13 (b) have always been retroactive. The referral of the situation in Darfur was adopted on the 31st March 2005 but refers the situation back to the 1st July 2002. The referral of the situation in Libya was adopted on the 26th February 2011 and refers the situation to the Court back to the 15th February 2011. Some of the arrest warrants that emerged from these referrals indeed concerned conduct occurring before the adoption of the referrals. For instance, Omar Al-Bashir, Head of State of Sudan, is accused of crimes committed between April 2003 and July 2008. ${ }^{13}$ Ahmad Harun, Ali Kushayb and Abdel Raheem Muhammad Hussein have all been accused of crimes committed in

$9 \quad$ However, see Cryer, Prosecuting International Crimes, 327-328.

$10 \quad$ See Chapter 1, section 9.

11 The Kampala Review Conference explicitly affirmed that the amendment on war crimes reflected customary international law. See Resolution RC/Res.5, par. 8-9; The other amendments were not accompanied by such affirmation.

12 The former ICC Prosecutor, Moreno Ocampo, has also suggested that retroactive jurisdiction could occur when a State has exempted itself from jurisdiction over war crimes for seven years under Article 124 Rome Statute, and then withdraws that exemption with retroactive effect; Andres Garibello and Jhon Torres Martınez, Corte Penal Internacional sigue pista a la parapolitica, asegura su fiscal jefe, Luis Moreno Ocampo, ElTiempo.com, 21 October 2007, available at http://www.eltiempo.com/justicia/2007-10-22/ARTICULOWEB-NOTA_INTERIOR-3776563.html.

13 See Decision to Issue an Arrest Warrant against Al-Bashir. 
Darfur between 2003 and 2004 - before the adoption of the referral. ${ }^{14}$ Further, in the Libyan situation, the arrest warrants against Muammar Gaddafi, Saif Gaddafi and Abdullah Al-Senussi were for crimes committed between 15th February 2011 and 28th February 2011; ${ }^{15}$ thus focusing mostly (or even exclusively in the case of Al-Senussi) on conduct that occurred before the referral.

The other situations where Article 13 (b) was considered were also intended to involve retroactive jurisdiction. The draft resolution to refer the situation in Syria to the ICC, presented before the SC in May 2014, proposed that the Court's jurisdiction extend back to March 2011. ${ }^{16}$ Another case worth mentioning is the $2014 \mathrm{UN}$ General Assembly resolution to urge the SC to refer the situation in North Korea since 1 July 2002 to the ICC under Article 13 (b) of the Rome Statute. ${ }^{17}$ This resolution followed a UN Commission of Inquiry report - issued in February 2014 documenting crimes against humanity committed in North Korea by the North Korean regime as far back as the 195 os. $^{18}$ Among the various acts amounting to crimes against humanity that the Commission reported gender-based persecution was singled out. ${ }^{19}$ In a footnote the report reads:

The Rome Statute introduced gender-based persecution as a crime against humanity, which was not yet included in the statutes of the ICTY and ICTR. In the opinion of the Commission, this norm is crystalizing into customary international law. ${ }^{20}$

Here, the Commission is not saying that gender-based persecution as a crime against humanity crystalized into customary international law in 2002 but that it is currently crystalizing into customary international law. In other words, the crime is not yet firmly established as a customary international norm in 2014

14 Prosecutor v. Harun Kushayb), Case No. ICC-02/05-01/o7, Warrant of Arrest for Ali Kuhayb, Warrant of Arrest for Ahmad Harun (Apr. 27, 2007); Prosecutor v. Hussein, Case No. ICC-02/05-01/12,Warrant of Arrest for Abdel Raheem Muhammad Hussein, 1 March 2012. See Prosecutor v. Gaddafi et al. Case No. ICC-o1/11-o1/11-1I, Decision on the "Prosecutor's Application Pursuant to Article 58 as to Muammar Mohammed Abu Minyar Gaddafi, Saif Al-Islam Gaddafi and Abdullah Al Senussi" (Jun. 27, 2011).

16 See UN Doc. S/2014/348, op. par. 2 (vetoed by China and Russia).

17 See the General Assembly resolution adopted on 18 December 2014 following action by its Third Committee (Social, Humanitarian and Cultural). See Press Release GA/11604. See also SC 7353rd Meeting (Dec. 22, 2014), UN Doc. S/PV.7353 (vetoed by China and Russia).

18 See Report of the detailed findings of the commission of inquiry on human rights in the Democratic People's Republic of Korea, UN Doc. A/HRC/25/CRP.1 (Feb. 7, 2014), fn. 1541.

19 Ibid., par. 1059 .

$20 \quad$ Ibid., fn. 1576, see also Ibid., par. 1139-1141 and fn. 1624. 
(the year when the report was written). ${ }^{21} \mathrm{~A}$ referral to the ICC under Article 13 (b) would however entail that conduct that occurred more than a decade ago but that is still in the process of crystallizing into customary international law in 2014 could be prosecuted before the ICC today.

The 'concept' of this book is the exercise of jurisdiction under Article 13 (b) over the territory and nationals of a State neither party to the Statute nor consenting to the ICC jurisdiction. The question that is addressed in this chapter is whether a full retroactive application of the Rome Statute's substantive criminal provisions to those accused who were outside of the ICC's jurisdiction at the time of the conduct may be a violation of the legality principle - especially non-retroactivity. It will be shown that the references in Article 22 (entitled nullum crimen sine lege) to "crimes within the jurisdiction of the Court" and to "entry into force of the Statute" in Article 24 (entitled non-retroactivity ratione personae) appear to sweep away the possibility for an accused to claim that the conduct which he or she is charged with was solely criminalized by the Rome Statute and not by any other law applicable to him or her at the time of the relevant conduct.

Section 1 will address the jurisdiction ratione temporis of the Court. This section will show that although the drafters of the Rome Statute wanted to establish the first international criminal jurisdiction strictly endowed with prospective jurisdiction, situations referred under Article 13 (b) or on the basis of a retroactive Article 12 (3) declaration of acceptance, can subject individuals to ex-post facto jurisdiction. Section 2 will examine the contours of the principle of legality. Section 3 will detail the scope and status of the principle of legality under human rights law. Then, section 4 will show how the specificity of international criminal law tainted the ad hoc tribunals' legacy. We will see in sections 5 and 6 that the drafters of the Rome Statute had intended to cure the various problems faced by previous international criminal tribunals by drafting a 'new international criminal code' to be applied prospectively. However, despite their lofty ambitions it seems the drafters barely scratched the surface of the issue of the principle of legality. Section 7 shows how a reading of the Statute under the 'universal jurisdiction conception' interplays with nullum crimen sine lege. Section 8 lists the various ways the 'Chapter VII conception' can tackle nullum crimen sine lege when the Court is exercising retroactive jurisdiction.

The purpose of this chapter is to assess whether referrals under Article 13 (b) clash with the principle of legality and how these clashes (if they exist)

21 See Cassese et al., Cassese's International Criminal Law, 108; Cryer, Prosecuting International Crimes, 260. 
may be avoided or resolved. The two 'conceptions' of a referral under Article 13 (b) Rome Statute adopted in this book will offer a different narrative of the Rome Statute's substantive criminal law and the ICC's exercise of jurisdiction. Hence proffering a different assessment of whether there are clashes between Article 13 (b) referrals and the principle of legality.

\section{1 \\ The Jurisdiction Ratione Temporis of the Court}

In 1919 the American delegation to the Traité de Versailles argued against the creation of an international criminal tribunal to try the crimes committed during World War I because it would be "the creation of a new tribunal, of a new law, of a new penalty, which would be ex post facto in nature and thus [...] in conflict with the law and practice of civilized communities"22 Two decades later some of the Allies, especially the British government, initially believed that the leaders of the Nazi regime should be punished by death without trial in order to avoid a trial in relation to which they "remained skeptical that a proper legal foundation could be found in existing international law."23

Eventually France, the United Kingdom, the United States and the Soviet Union agreed in 1945 to establish the Nuremberg Tribunal "for the just and prompt trial and punishment of the major war criminals of the European Axis." ${ }^{24}$ The same was done in Tokyo for "the just and prompt trial and punishment of the major war criminals in the Far East."25 However, the Nuremberg and Tokyo Tribunals were widely criticized for their infringements upon the principle of legality. ${ }^{26}$ Both Tribunals exercised retroactive jurisdiction covering acts committed before their establishment. Similarly, the ICTY, the ICтR and the Special Court for Sierra Leone (SCSL) were established with retroactive jurisdiction. ${ }^{27}$ Conversely, the ICC is said to be a prospective institution;

22 Lansing and Brown Scott, Memorandum of Reservations Presented by the Representatives of the United States to the Report of the Commission on Responsibilities, 4 April 1919, Annex II to Commission on the Responsibility of the Authors the War and on Enforcement of Penalties, Report Presented to the Preliminary Peace Conference (Versailles, 29 march 1919).

23 Overy, The Nuremberg Trials, 7.

24 London Charter, Art. 1.

25 Tokyo Charter, Art. 1.

26 See e.g. Tomuschat, "Legacy of Nuremberg," 830-837.

27 ICTY Statute Art. 8; ICTR Statute Art. 1; SCSL Statute Art. 1(1); Schabas, An Introduction, 70, fn. 35 . 
the Court can only exercise jurisdiction over acts committed after the entry into force of its Statute. ${ }^{28}$

The two paragraphs of Article 11 of the Rome Statute - stipulating the jurisdiction ratione temporis of the ICC-make a distinction between the entry into force of the multilateral treaty that is the Rome Statute and the entry into force of the Rome Statute for a specific State. ${ }^{29}$ Article 11 (1) states that " $[t]$ he Court has jurisdiction only with respect to crimes committed after the entry into force of this Statute." The Rome Statute entered into force on 1 July 2002. ${ }^{30}$ Article 11(2) operates a dichotomy by regulating the jurisdiction of the Court for States that ratify the Rome Statute after its entry into force in a different manner. ${ }^{31}$ Article $11(2)$ reads as follows:

If a State becomes a Party to this Statute after its entry into force, the Court may exercise its jurisdiction only with respect to crimes committed after the entry into force of this Statute for that State, unless that State has made a declaration under Article 12, paragraph $3 \cdot{ }^{32}$

Thus, at first reading it appears that the Rome Statute affirms that the ICC's jurisdiction can only be exercised ad futurum. Nevertheless, Article 11 (2) is subjected to an internal exception. Indeed, the last part of Article 11 (2) Rome Statute makes clear that the ICC can only exercise jurisdiction with respect to crimes committed after the entry into force of the Statute for that State, "unless that State has made a declaration under Article 12, paragraph 3." Article 12 (3) of the Rome Statute permits States not party to the Rome Statute to accept ad hoc the exercise of the Court's jurisdiction. It also allows States that ratified the Statute after its entry into force to accept the jurisdiction of the Court for acts committed prior to ratification but after the entry into force of the Statute, 1 July 2002. Thus, read in conjunction with Article 11 (2) Rome Statute, Article 12 (3) Rome Statute allows a State to provide retroactive jurisdiction to the Court. Article 11 is silent with respect to the jurisdiction ratione temporis of the ICC in situations referred under Article 13 (b) except that the Court has no

28 See Rome Statute, art. 11(1). As for the issue of whether the SC is bound by this date, see Schabas, An Introduction, 71; Condorelli and Villalpando, "Can the Security Council Extend," $571-582$. This issue will be addressed comprehensively in Chapter 5 .

29 Heugas-Darraspen, "Article 22," 567.

30 On the 11 April 2002, in addition to the fifty States that had already ratified the Statute, ten States simultaneously deposited their instruments of ratification as provided by Article 126 and consequently the Rome Statute entered into force on 1 July 2002.

31 See vClT, Art. 24(3).

32 Rome Statute, Art. 11(2). 
competence before 1 July 2002. ${ }^{33}$ Therefore, the temporal jurisdiction of the Court can be retroactively triggered by the SC up to the entry into force of the Rome Statute.

Accordingly, the Rome Statute allows the ICC, especially in situations triggered under Article 13 (b), to exercise its jurisdiction over a situation even if the crime was committed by a national and in the territory of State in which the Statute was not into force at the time of the conduct. The only temporal limit that is firmly set on the ICC exercise of jurisdiction is the entry into force of the Statute, that is 1 July 2002. The question that is asked in this chapter is whether such retroactive exercise of jurisdiction conflicts with the principle of legality. As such, it is necessary to define the contours of the principle of legality.

The principle of legality, as Kenneth S. Gallant has defined it, "is a requirement that the specific crimes, punishments and courts be established legally - within the prevailing legal system." ${ }^{34}$ This definition can be broken down into three rules: (1) no crime without law (nullum crimen sine lege); (2) no punishment without law (nulla poena sine lege); and, (3) no court without law.

The most important precept of the principle of legality for the purpose of this chapter is nullum crimen sine lege (no crime without law). ${ }^{35}$ Nullum crimen sine lege encapsulates four basic notions: (1) nullum crimen sine lege praevia (nonretroactivity); (2) nullum crimen sine lege scripta (written law); (3) nullum crimen sine lege certa (specificity); (4) nullum crimen sine lege stricta (strict construction).

According to nullum crimen sine lege scripta, the law needs to be written and enacted otherwise there is no law and therefore no criminal liability. Nullum crimen sine lege scripta poses a challenge to common law jurisprudence and customary criminal law. In order to accommodate these legal systems, written as well as unwritten law are said to satisfy nullum crimen sine lege. ${ }^{36}$ Nullum

33 See Rome Statute, Art. 11 (1); see Chapter 5 .

34 Gallant, The Principle of Legality, 15.

35 We will not deal with the last rule (i.e. no court without law) in this chapter, but in Chapter 5, section 4. See Gallant, The Principle of Legality, 11-12 (for a more exhaustive list).

36 To alleviate the prejudice to the accessibility of case law, the ECtHR replaced its reference to written and unwritten law by "statutory law as well as case-law"; See Cantoni v. France, Grand Chamber, Judgment, ECtHR, Application No. 17862/91, 15 November 1996, par. 29; Sunday Times v. United Kingdom, Court, Judgment, ECtHR, Application No. 6538/74, 26 April 1979, par. 47; see Gallant, The Principle of Legality, 261 (nullum crimen sine lege scripta is not necessarily required under international human rights law). 
crimen sine lege certa expresses the value of legal certainty. Clarity, precision, certainty and specificity are generally the requirements for a law to be considered in accordance with nullum crimen sine lege certa. ${ }^{37}$ In order to alleviate the risks posed by vague laws or general definitions, criminal provisions must be interpreted strictly. Nullum crimen sine lege stricta encompasses two principles, first the judiciary cannot broadly or extensively interpret a criminal rule and, relatedly, it cannot define criminal acts by analogy to existing crimes. These prohibitions imply that criminal rules must be strictly construed. ${ }^{38}$

The most prevalent notion of the principle of nullum crimen sine lege is the rule of non-retroactivity. Nullum crimen sine lege praevia is the notion that there is no crime without preexisting law. A behavior can be held criminal only if at the time it was committed there was a law providing for its criminalization. The law must have been in force at the time the conduct took place and must have been applicable to the conduct in question. The core of nullum crimen sine lege is in non-retroactivity, while the concept of written law, the rule of specificity, and the rule of strict construction are tools to ensure that retroactive creation of crimes does not take place. ${ }^{39}$ The aim of all these notions is to act as safeguards against an arbitrary exercise of authority. ${ }^{40}$

While nulla poena sine lege will not be the focus of this chapter, it will resurface in various parts of it, especially if in order to comply with non-retroactivity one has to look to domestic legislation to determine whether the acts were criminal according to the law applicable at the time of the impugned conduct. ${ }^{41}$ Nulla poena sine lege encapsulates the same basic notions as its counterpart (nullum crimen sine lege) plus the rule of lex mitior (retroactivity in mitius). ${ }^{42}$

\section{The Status and Scope of Nullum Crimen Sine}

Lege in International Human Rights Law

Nullum crimen and nulla poena sine lege are contained in Article 11(2) of the Universal Declaration of Human Rights (UDHR), ${ }^{43}$ Article 15 of the

37 Prosecutor v. Stakic, Case No. IT-97-24-T, Judgment (Jul. 31, 2003), par. 719.

38 Cassese et al., Cassese's International Criminal Law, 33.

39 Gallant, The Principle of Legality, 352-355; Bassiouni, "Human Rights in the Context," 29o291; See also Schlutter, Customary International Law, 297.

40 See Mokhtar, "Nullum Crimen," 41.

41 See section 8.5 of this chapter.

42 Dana, "Beyond Retroactivity," 868; Universal Declaration of Human Rights, GA Res. 217A (III), UN Doc A/810 at 71 (Dec. 10, 1948), Article 11 (2) (hereinafter UDHR).

Ibid. 
International Covenant on Civil and Political Rights (ICCPR) ${ }^{44}$ Article 7 of the European Convention on Human Rights (ECHR), ${ }^{45}$ Article 9 of the Inter American Convention on Human Rights (IACHR), ${ }^{46}$ Article 6 and 7(2) of the African Charter on Human and People's Rights (ACHPR) ${ }^{47}$ and Article 15 of the revised Arab Charter on Human Rights (ACHR). ${ }^{48}$ Article 4 ICCPR, Article 15 (2) ECHR and Article 27 IACHR stipulate that even in a state of emergency the principle of legality cannot be derogated from. Furthermore, Article 99(1) of the Geneva Convention III, ${ }^{49}$ Article 67 of Geneva Convention IV, ${ }^{50}$ Article 75(4)(c) of Additional Protocol I ${ }^{51}$ and Article 6(2)c) of Additional Protocol II $^{52}$ also provide for the application of nullum crimen/nulla poena sine lege in times of armed conflict - both international and non-international. Accordingly, it appears that the international community agreed that nullum crimen/ nulla poena sine lege must be respected even at times when the rule of law is at utmost risk. ${ }^{53}$

On the basis of the universal ratification of these treaties it is generally considered that nullum crimen/nulla poena sine lege are customary international norms. ${ }^{54}$ The best expression of nullum crimen/nulla poena sine lege is provided in Article 11(2) UDHR, which reads as follows:

No one shall be held guilty of any penal offence on account of any act or omission which did not constitute a penal offence, under national or international law, at the time when it was committed. Nor shall a heavier penalty be imposed than the one that was applicable at the time the penal offence was committed. ${ }^{55}$

44 International Covenant on Civil and Political Rights (Dec. 16, 1966), 999 U.N.T.S. 171 (hereinafter ICCPR).

45 European Convention for the Protection of Human Rights and Fundamental Freedoms (Nov. 4, 1950) 213 U.N.T.S. 221 (hereinafter ECHR).

46 American Convention on Human Rights (Nov. 21, 1969) 1144 U.N.T.S. 123, (IACHR).

47 African Charter on Human and Peoples' Rights (June 27, 1981) 1520 UNTS 217 (hereinafter ACHPR).

48 Arab Charter on Human Rights (May 22, 2004), reprinted in 12 International Human Rights Report 893 (2005), (entered into force March 15, 2008)

49 Geneva Convention III.

50 Geneva Convention IV.

51 Protocol Additional I.

52 Protocol Additional II.

53 Gallant, The Principle of Legality, 208.

54 Gallant, The Principle of Legality, 3; Lamb, "Nullum Crimen," 734-742. For nulla poena sine lege see Gallant, The Principle of Legality, 379.

55 UDHR, Art. $11(2)$. 
This provision recognizes that international law as much as national law is a relevant source of law for the criminalization and punishment of a conduct. Hence, if an act was lawful according to national law but criminal under international law the perpetrator can be prosecuted and punished without violating the principle of non-retroactivity. ${ }^{56}$ This formulation of nullum crimen/ nulla poena sine lege praevia must be understood in accordance with Nuremberg Principle No. 2 which states that "[t]he fact that internal law does not impose a penalty for an act which constitutes a crime under international law does not relieve the person who committed the act from responsibility under international law." 57

The ICCPR and the ECHR contain a provision that is similar to the UDHR's provision on nullum crimen/nulla poena sine lege. However, in contrast with the UDHR, the ICCPR has a further paragraph which specifies that the rules contained in the previous paragraph does not "prejudice the trial and punishment of any person for any act or omission which, at the time when it was committed, was criminal according to the general principles of law recognized by the community of nations." ${ }^{58}$ The ECHR has in essence a similar second paragraph. ${ }^{59}$ This second paragraph is also known as the 'Nuremberg clause' as it is claimed to have been drafted to eliminate any doubt about the validity of the post-World War II prosecutions. ${ }^{60}$

These paragraphs are in fact repeating a source - international law - contained in the first paragraphs of the non-retroactivity provisions. General principles of law are a recognized source of international law, indeed they are explicitly listed in Article 38 (1) (c) of the Statute of the International Court of Justice. ${ }^{61}$ As Machteld Boot argues, the 'Nuremberg clause' was inserted in order to secure and confirm the findings of the Nuremberg Tribunal but it does not add anything to the sources for the criminalization of conducts. ${ }^{62}$ The ECtHR held in its most recent jurisprudence that the two paragraphs of Article 7 are interlinked and are to be interpreted in a concordant manner. ${ }^{63}$ Thus,

\footnotetext{
56 Spiga, "Non Retroactivity," 13.

57 Nuremberg Principles No. II.

$5^{8}$ ICCPR, Art. $15(2)$.

59 ECHR, Art. $7(2)$.

6o See Gallant, The Principle of Legality, 182; Boot, Nullum Crimen Sine Lege, 137-140; 158 161,628 .

61 ICJ Statute, Art. 38 (c).

62 See Boot, Nullum Crimen Sine Lege, 140; see also Nowak, CCPR Commentary, 281

63 Kononov v. Latvia, Grand Chamber, Judgment, ECtHR, Application No. 36376/o4, 17 May 2010, par. 186; Maktouf and Damjanovic v. Bosnia and Herzegovina, Grand Chamber, Judgment, ECtHR, Application No. 2312/o8, 18 July 2013, par. 72.
} 
Article 7(2) ECHR and 15(2) ICCPR do not provide exceptions to nullum crimen/nulla poena sine lege but simply reiterate that general principles of law although an unwritten source of law - can also be used as a source of law in the assessment of the applicable law at the time of the conduct.

The strict application of the notions of written law (lex scritpa), specificity (lex certa), strict construction (lex stricta) and non-retroactivity (lex praevia) to international criminal law is often challenged on the ground that the peculiarity of international law needs to be taken into account. For instance, the ICTR said that "given the specificity of international criminal law, the principle of legality does not apply to international criminal law to the same extent as it applies in certain national legal systems." ${ }^{4}$ Indeed, the criminalization process in international law is not the same as in national law. While the criminalization process in national law is generally through legislative acts, in international law there is no international legislature. On an ad hoc basis States may agree to draft a treaty which will regulate inter-State affairs. Rarely do those treaties directly criminalize the conduct of individuals.

Nevertheless, there have been various instances where courts were given jurisdiction to prosecute individuals for having violated treaties. According to Article 227 of the 1919 Versailles Peace Treaty, the Allied and Associated Powers accused the former German Emperor William II of "a supreme offence against international morality and sanctity of treaties". ${ }^{65}$ Article 5 of the Nuremberg Charter and Article 6 of the Tokyo Charter also provided, among the crimes against peace, waging war "in violation of international treaties, agreements and assurances". The Nuremberg Tribunal established that although there were no provisions on punishment in the Kellogg-Briand Pact this did not mean that individual criminal responsibility could not ensue from its violation. Similarly, the ICTY found that it had jurisdiction over "violations of agreements binding upon the parties to the conflict, considered qua treaty law, i.e. agreements which have not turned into customary international law."66

64 Prosecutor v. Karemera et al, Case No. ICTR-98-44-T, Decision on the Preliminary Motions by the Defence of Joseph Nzirorera, Edouard Karemera, Andre Rwamakuba and Mathieu Ngirumpatse Challenging Jurisdiction in Relation to Joint Criminal Enterprise (May 11, 2004), par. 43 .

65 Treaty of Versailles of 28 June 1919, Art. 227.

66 Tadic Interlocutory Appeal Decision, par. 89. 
Nonetheless, some scholars have rejected the Nuremberg Tribunal's holding that violations of the Kellog-Briand Pact and other treaties entailed individual criminal responsibility. ${ }^{67}$ The same criticism has been expressed as to the ICTY's holding that there is individual criminal responsibility for violations of agreements binding upon the parties to a conflict. ${ }^{68}$ It is indeed a truism to state that an illegal act is not necessarily a crime. ${ }^{69}$ Furthermore, the question of individual criminal responsibility is in principle distinct from the question of State responsibility. ${ }^{70}$ Unlawful acts of States may possibly result in the international responsibility of the State, but this unlawful act of the State will not necessarily entail that the agents of the State are criminally responsible. Most international law does not directly bind individuals. ${ }^{71}$ Moreover, the fact that a certain international rule seems to define a crime does not entail ipso facto that individual criminal responsibility arises. ${ }^{72}$ The ILC in its commentary to its Draft Code of Crimes against the Peace and Security of Mankind (1994) stated the following:

the mere existence of a treaty definition of a crime may be insufficient to make the treaty applicable to the conduct of individuals. No doubt such cases (which are also likely to be rare, and may be hypothetical) might raise issues of the failure of a State to comply with its treaty obligations, but that is not a matter which should prejudice the rights of an individual accused. ${ }^{73}$

Indeed, for individual criminal responsibility to arise the treaty needs to be properly applicable to the conduct of the accused in question according to its terms or because the treaty was part of the domestic law.

The same contention exists as to customary international law: the violation of a customary norm may entail the responsibility of the State but this violation in itself does not necessarily entail that the criminal liability of the individual who committed the act is engaged. In principle, the requirement of

67 See, e.g., Schick, Crimes against Peace, 770; see Tomuschat, "Legacy of Nuremberg," 832833 .

68 See e.g. Degan, “On the Sources" 64.

69 Bassiouni, Crimes Against Humanity, 113.

70 Draft Articles on Responsibility of States for Internationally Wrongful Acts, with commentaries 2001, p. 143.

71 Tomuschat, "Legacy of Nuremberg," 833.

72 See Kress, "International Criminal Law", par. 12.

73 ILC, Report of the ILC on the Work of its 46th Session, UN Doc. A/49/10 (1994). 
specificity entails that the actus reus, the mens rea and the modes of responsibility must be specified in the corpus criminalizing the conduct. ${ }^{74}$ The corpus of customary international law is rarely that detailed and intelligible. Indeed, Verhoeven asks:

how could a private person be satisfactorily informed of the existence or exact content of a customary international rule or of a general principle of law, which the states themselves very often remain largely ignorant of and which are far from constituting for the individuals 'clear' and 'accessible' norms satisfying the nullum crimen, nulla poena requirements? ${ }^{75}$

Customary international law by its very nature can be even more imprecise than treaty law. ${ }^{76}$ The refusal by a Trial Chamber of the ICTY in Prosecutor $v$. Vasiljevic to convict an accused for the war crime of 'violence to life and person' as it was deemed not to be sufficiently defined in customary international law shows the challenges customary international law poses to the principle of legality. ${ }^{77}$

It is nevertheless recognized that customary international law may be used as source of international law under which individual criminal responsibility arises. The Tadic Interlocutory Appeal Decision confirmed that individual criminal responsibility can attach to a breach of a customary prohibition of certain conduct. ${ }^{78}$ Moreover, the report of the Secretary General on the establishment of the ICTY had determined that "the application of the principle nullum crimen sine lege requires that the tribunal should apply rules of international humanitarian law which are beyond any doubt part of customary international law." ${ }^{\prime 9}$ Thus, the ICTY exercised its jurisdiction according to the following rules:

[T] he Tribunal only has jurisdiction over a listed crime [in the Statute] if that crime was recognised as such under customary international law at the time it was allegedly committed. The scope of the Tribunal's jurisdiction ratione materiae may therefore be said to be determined both

74 See Blakesley, "Atrocity and Its Prosecution," 206.

75 Verhoeven, "Article 21 of the Rome Statute," 22.

76 Lamb, "Nullum Crimen," 743; see Ambos, "Treaty-Based Universal System," 163.

77 Prosecutor v. Vasiljevic, Case No. IT-98-32-T, Judgment (Nov. 29, 2002), par. 193.

78 Tadic Interlocutory Appeal Decision, par. 134.

79 Report of the Secretary-General pursuant to paragraph 2 of Security Council resolution 808 (1993), UN Doc. S/25704 (May 3, 1993), par. 34. 
by the Statute, insofar as it sets out the jurisdictional framework of the International Tribunal, and by customary international law, insofar as the Tribunal's power to convict an accused of any crime listed in the Statute depends on its existence qua custom at the time this crime was allegedly committed. ${ }^{80}$

The second condition was designed to ensure that the ICTY complies with the obligation to apply the principle of nullum crimen sine lege praevia (non-retroactivity). ${ }^{81}$ The same requirements were held for the modes of liabilities. ${ }^{82}$

The ad hoc tribunals have been nevertheless accused of legislating new law under the guise of discovering customary international law ${ }^{83}$ - especially through its case law on war crimes, ${ }^{84}$ crimes against humanity, ${ }^{85}$ command responsibility, ${ }^{86}$ and joint criminal enterprise ${ }^{87}$ While the progressive findings of the ad hoc tribunals on war crimes and crimes against humanity greatly contributed to the codification process at the Rome Conference, ${ }^{88}$ Article 27 Rome Statute does not include the doctrine of joint criminal enterprise III as designed by the ad hoc tribunals, ${ }^{89}$ and Article 28 Rome Statute, unlike the ad hoc tribunals, requires a causal link for command responsibility to be found. ${ }^{90}$ Undeniably, the ad hoc tribunals participated in the development of international law; however, it was felt in Rome that if a permanent international criminal court was to be established, States should make the law and not the judges.

8o Prosecutor v. Milutinovic et al., Case No. IT-99-37-AR72, Decision on Dragoljub Ojdanic's Motion Challenging Jurisdiction - Joint Criminal Enterprise (May 21, 2003), par. 9.

81 Prosecutor v. Milutinovic et al. Case No. IT-05-87-PT, Decision on Ojdanic's Motion Challenging Jurisdiction: Indirect Co-Perpetration (Mar. 22, 2006), par. 15.

$82 \quad$ Ibid.

83 See e.g. Zahar and Sluiter, International Criminal Law, 93-105.

84 See Darcy, "The Reinvention of War Crimes," 127.

85 See van den Herik, "Using Custom," 80-105; Schabas, An Introduction, 109-110.

86 See e.g. Prosecutor v. Delalic et al., Case No. IT-96-21-T, Judgment (Nov. 16, 1998), par. 399; see Mettraux, Command Responsibility, 83 .

87 See Prosecutor v. Tadic, Case No. IT-94-1-A, Judgment (Jul. 15, 1999), par. 226; See e.g., Danner and Martinez, "Development of International Criminal Law," 146; Gibson, "Testing the Legitimacy," 522 .

88 For war crimes, see Darcy, "The Reinvention of War Crimes," 118; For crimes against humanity, see van den Herik, "Using Custom," 104-105.

89 Oberg, "Fact-Finding without Facts," 319.

9o Mettraux, Command Responsibility, 85 . 


\section{The Rome Statute Distances Itself from the Previous International Criminal Tribunals}

At the 1996 Preparatory Committee on the Establishment of an International Criminal Court, there was broad agreement that "the crimes within the jurisdiction of the Court should be defined with clarity, precision, and specificity required for criminal law in accordance with the principle of legality (nullum crimen sine lege)." ${ }^{1}$ As the President of Italy noted at the Rome Conference, "[t]he ad hoc tribunals set up for the former Yugoslavia and Rwanda represented positive advances, but [...] [c]riminal law should always precede crimes; it should be known that the crimes were punishable by law and what the penalties would be." 92 The Rome Statute reflected this conviction by setting out a 'new code of international criminal law', which defines the crimes within the jurisdiction of the Court and the general principles of liability in unprecedented detail. ${ }^{93}$ The definitions of the crimes are even further elaborated in the Elements of Crimes which are to be used by the Court in the interpretation and application of Articles 6, 7, 8 and 8bis. ${ }^{94}$ Cassese observed that the framers of the Rome Statute attempted "to set out in detail all the classes of crimes falling under the jurisdiction of the Court, so as to have a lex scripta laying down the substantive criminal rules to be applied by the ICC."95

Article 21 of the Rome Statute sets out that the primary sources upon which the ICC can base a finding that certain conduct is punishable is the Statute itself, the Elements of Crimes (which have to be consistent with the Statute) ${ }^{96}$ and the RPE. ${ }^{97}$ Customary international law and general principles of law can only be considered if these sources leave a lacuna and this lacuna cannot be filled by the application of the rules of interpretation as contained in the Vienna Convention on the Law of Treaties. ${ }^{98}$ Grover observes "that the drafting of Article 21 was motivated by the principle of legality and the desire to limit judicial

91 Report of the Preparatory Committee on the Establishment of an International Criminal Court (Vol I, Proceedings of the Preparatory Committee), in UN GAOR, 51st Session, Supp. No. 22A, Doc. (A/51/22), 1996, par. 52 .

92 United Nations Diplomatic Conference of Plenipotentiaries on the Establishment of an International Criminal Court, Rome (June 1998) Official Records, Vol II, Summary records of the plenary meetings, 1st Plenary Meeting, 15 June 1998, par. 16, p 62.

93 See Cryer et al., International Criminal Law and Procedure, 150-151.

94 Rome Statute, Art. 9 and 21; See Schabas, Commentary on the Rome Statute, 407.

95 Cassese, "Preliminary Reflections," 152.

96 Rome Statute, Art. 9(3).

97 Rome Statute, Art. 52(5).

98 Decision to Issue an Arrest Warrant against Al-Bashir, par. 126; Prosecutor v. Katanga, Case No. ICC-o1/o4-o1/o7-3436, Jugement rendu en application de l'Article 74 du Statut (Mar. 8, 2014), par. 38-42; See also e.g., Prosecutor v. Ruto et al., Case No. ICC-o1/o9-01/11-373, 
discretion in the interpretation and application of the Rome Statute." ${ }^{\prime 99}$ The degree of discretion afforded to judges by the hierarchy established in Article 21 is further limited by Article 22 - the first provisions on 'nullum crimen sine lege' ever inserted in the Statute of an international criminal jurisdiction. The nullum crimen sine lege principle as adopted under the Rome Statute is intended to exclude any possibility that the Court tries customary law offences. ${ }^{100}$ Moreover, Article 22 (2) further limits the possibility for judicial law-making by providing that "[t]he definition of a crime shall be strictly construed and shall not be extended by analogy. In case of ambiguity, the definition shall be interpreted in favor of the person being investigated, prosecuted or convicted."

While Cassese stated that the Rome Statute "seems to evince a certain mistrust in the Judges", 101 Judge Hunt adds that "[i]t would be more accurate to say that the Statute evinces a deep suspicion of the Court's judges."102 Schabas comments:

we may well ask if the elaborate subject matter jurisdiction provisions in the Rome Statute, not to mention the obsessive exercise in legal positivism known as the Element of Crimes, as well as the entranchement of the 'strict construction' principle in Article 22 (1), were reactions to the innovations of Judge Cassese and his colleagues in their interpretation of the ad hoc Tribunal Statutes. ${ }^{103}$

It is true that the Rome Statute significantly departs from the previous international criminal tribunals' Statutes, as it attempts to strictly comply with the notions of written law (lex scritpa), specificity (lex certa), strict construction (lex stricta) and non-retroactivity (lex praevia). After all, the Rome Statute is establishing an international criminal court endowed with a jurisdiction that can be used to try the drafters' own State agents. ${ }^{104}$ "This awareness", as Broomhall puts it, "put a premium on the clear delimitation of the Court's jurisdiction."105

Decision on the Confirmation of Charges Pursuant to Article 61(7)(a) and (b) of the Rome Statute (Jan. 23, 2012), par. 289; Schlutter, Customary International Law, 322.

99 Grover, Interpreting Crimes, 116; see also deGuzman, "Article 21," 442.

100 Schabas, "General Principles," 408.

101 Cassese, "Preliminary Reflections," 163.

102 Hunt, "High Hopes," 61.

103 Schabas, "Interpreting the Statutes," 887; See also Prosecutor v. Katanga, Case No. ICC-o1/ 04-01/07, Jugement rendu en application de l'Article 74 du Statut, Minority Opinion of Judge Christine Van den Wyngaert (Mar 8, 2014), par. 19.

104 Grover, "A Call to Arms," 552 (2010); Cryer, Prosecuting International Crimes, 236, 287; Broomhall, "Article 22," 714.

105 Broomhall, "Article 22," 714. 
However, the drafters might have thrown out the baby with the bathwater in their commitment to circumscribe the Court's powers. Paradoxically, as we will see in the next section, the very provisions drafted to ensure compliance with the principle of legality might lead the ICC-in situations triggered under a retroactive Article 13 (b) referral or on the basis of a retroactive Article 12 (3) declaration of acceptance - to convict individuals for conduct that was criminal only according to the Rome Statute but not under the law applicable to the accused.

\section{A Statute Applicable since Its Entry into Force}

Although the Rome Statute states that the ICC can only exercise jurisdiction over a crime committed after the entry into force of the Rome Statute, it also provides permission for retroactive referrals to the ICC if a situation is triggered under Article 13 (b) or a State has issued a retroactive Article 12 (3) declaration of acceptance. Regardless of the trigger mechanism used to activate the Court's jurisdiction, and whether such jurisdiction is retroactive, the Statute provides the ICC with jurisdiction over genocide, crimes against humanity, war crimes and aggression. ${ }^{106}$ These crimes are defined 'for the purpose of this Statute' in Articles 6, 7, 8 and 8bis. The Elements of Crimes drafted by the Assembly of States Parties shall assist the Court in the interpretation and application of Articles 6, 7, 8 and 8bis. The modes of liabilities under which the Court can find an accused responsible of a crime defined in Articles 6, 7, 8 and 8bis are those listed in Article 25 (3) and (3) bis. In addition to the modes listed in Article 25, Article 28 defines how military commanders and other superiors may be found criminally responsible for crimes within the jurisdiction of the Court.

As mentioned above, Article 21 (1) (a) of the Rome Statute sets that the primary sources for the ICC to find a conduct punishable is the Statute itself, the Elements of Crime, ${ }^{107}$ and the RPE. ${ }^{108}$ Other sources of law - Article 21 (1) (b) and (c) - can only be resorted to when two conditions are met: (i) there is a lacuna in the written law contained in the Statute, the Elements and the RPE; and (ii) the lacuna cannot be filled by the application of the interpretive

106 However, temporal Jurisdiction over aggression and other amendment crimes is governed by the respective amendment entry into force, see section 6.1 of this chapter.

107 Rome Statute, Art. 9(3).

108 Rome Statute, Art. 52(5). 
methods set out in the VCLT. ${ }^{109}$ In other words, if a crime or a mode of liability is defined in the Statute, the Court has no reason to resort to other sources of international law. ${ }^{110}$

One may think that the article on nullum crimen sine lege entitles the Court to verify whether a crime or mode of liability provided in the Statute was established under a customary international norm or another norm applicable to the conduct in question at the time it occurred. However, Article 22 (1) of the Rome Statute only states that "[a] person shall not be criminally responsible under this Statute unless the conduct in question constitutes, at the time it takes place, a crime within the jurisdiction of the Court." To be within the jurisdiction of the Court, the crime has to be within the jurisdiction ratione materiae of the Court, as spelled out in Article 5, 6, 7, 8 and 8bis, at the time when the conduct occurred. ${ }^{111}$ Further, if the individual can be held responsible for this crime according to one of the modes of liability listed in Article 25 or is responsible under Article 28, the conduct falls within the jurisdiction of the Court. In other words, if the crime and the mode of liability were defined in the Statute at the time the conduct took place, Article 22 is of no resort, even if the conduct occurred before the date when the SC referred the situation under Article 13 (b). ${ }^{112}$ Indeed, Article 22 does not leave space to argue that although a crime or a mode of liability was within the jurisdiction of the Court, it did not apply to the accused at the time of the conduct in question.

It could be argued that if the crime had been committed by a national of a non-party State in the territory of a non-party State, it was not at the time it took place within the jurisdiction of the Court. Indeed, the Court under such reading of jurisdiction would lack jurisdiction ratione loci and personae over the conduct. Accordingly, Article 22 would apply and bar the ICC from exercising retroactive jurisdiction. However, prima facie that does not seem to be the intention of the drafters, at least in 1998. Article 12 (3) was drafted to ensure

109 Decision to Issue an Arrest Warrant against Al-Bashir, par. 44; See also e.g Prosecutor v. Ruto et al., Case No. ICC-o1/o9-o1/11-373, Decision on the Confirmation of Charges Pursuant to Article 61(7)(a) and (b) of the Rome Statute (Jan. 23, 2012), par. 289.

110 Prosecutor v. Ruto et al., Case No. ICC-o1/o9-o1/11-373, Decision on the Confirmation of Charges Pursuant to Article 61(7)(a) and (b) of the Rome Statute (Jan. 23, 2012), par. 289 ("the Chamber should not resort to applying Article 21 (b), unless it has found no answer in paragraph (a).").

111 It is even unsure whether Article 22 applies to modes of liabilities, since it refers only to 'crime'. Broomhall, "Article 22," 723-724; However, see Schabas, Commentary on the Rome Statute, 410 .

112 See also Bartels, "Legitimacy and ICC Jurisdiction," 159-16o. 
that States could provide retroactive jurisdiction to the Court up to the Statute's entry into force even if they accessed it at a later stage. ${ }^{113}$ Indeed, it has already been used in this manner by Uganda, Côte d'Ivoire, and Palestine. ${ }^{114}$ The intention of the drafters cannot have been to render Article 12 (3) - read in conjunction with Article 11 - meaningless. As for referrals under Article 13 (b), the provision itself notes that the SC may refer a "situation in which one or more of such crimes appears to have been committed". It thus contemplates the idea that referrals can capture crimes that occurred in the past. It even requires that one or more crime appear to have been committed for the SC to trigger the jurisdiction of the Court. It would be illogical and legally unsound if the SC had to witness the commission of crimes to refer a situation to the Court while the latter is forbidden by its Statute to investigate and prosecute the crimes that prompted the referral. Furthermore, as mentioned above, Article 13 (b) was always used to provide retroactive jurisdiction to the ICc. ${ }^{115}$ Indeed, the Statute would be inconsistent if it allowed, on the one hand, retroactive referrals under Article 13 (b) and retroactive Article 12 (3) declarations while, on the other hand, prohibited the ICc from exercising retroactive jurisdiction. Consequently, the requirement that the crime be "within the jurisdiction of the Court" in Article 22 does not include the jurisdictional prerequisites contained in Article $12(2)$ - personal or territorial jurisdiction. Instead the Statute's provision on nullum crimen sine lege strictly focuses on whether or not the crime and modes of liability were defined in the Statute at the time of the conduct in question.

Article 24 (1) Rome Statute governs non-retroactivity ratione personae as follows: "[n]o person shall be criminally responsible under this Statute for conduct prior to the entry into force of the Statute." Simply, Article 24 (1) specifies that the Statute must be in force prior to the relevant conduct in order for criminal responsibility to be found by the Court. ${ }^{116}$ The Statute entered into force in July 2002. For any conduct occurring after that date, Article 24 is of no avail. Indeed, it seems that Article 24 does not prevent the ICC from finding an individual criminally responsible for conduct that, at the time it took place, was criminalized under the Rome Statute solely, even if the conduct occurred

113 See Rome Statute, Art. 11.

114 Retroactive declaration of acceptance have been upheld by the Appeals Chamber in particular in Prosecutor v. Gbagbo, Case No. ICC-02/11-01/11 OA 2, Judgment on the Appeal of Mr. Laurent Koudou Gbagbo against the Decision of Pre-Trial Chamber I on Jurisdiction and Stay of the Proceedings (Dec. 12, 2002), para. 84. Ukraine issued two retroactive declaration under Article 12 (3) but has not acceded to the Rome Statute.

115 See vClt, Art. 31 (3) (b).

116 Lamb, "Nullum Crimen," 751-752. 
prior to an act making the Rome Statute applicable in the territorial and national State. ${ }^{117}$ As Milanovic observes:

the irony is that the very provision that is meant to establish 'nonretroactivity ratione personae' appears to allow for precisely such retroactivity, since an individual could be prosecuted for an act committed while he was not a national of a State Party, nor in a State Party's territory.118

The only unequivocal limit to the jurisdiction of the Court is the entry into force of the Statute per se, the 1st July $2002 .{ }^{119}$ While the ratio legis behind these provisions was to ensure that the Court abides by the strictest standard of legality, they actually leave no room for a challenge to the ICC's jurisdiction on the basis that the crimes contained in the Statute were not applicable to the accused at the time of the impugned conduct.

\subsection{Exception for the Crimes Adopted after the Entry into Force of the Statute?}

The Court' jurisdiction over the crime of aggression and 'new' war crimes is regulated by the entry into force of each respective amendment. The Court's jurisdiction over the crime of aggression can only be exercised after 17 July $2018 .{ }^{120}$ As to the war crimes amendments, Article 8(2)(e) (xiii), (xiv), (xv) entered into force on 26 September 2012 for the Court, and for the first State, San Marino, which ratified the amendment. ${ }^{121}$ Articles 8 (2) (b) (xxvii), (xxviii), (xxix) and 8(2)(e)(xvi), (xvii), (xviii) will enter into force for the Court one year after its ratification by at least one State.

Given that the aggression amendments, explicitly provides in Article 15 ter that the SC can trigger the Court jurisdiction over Article 8bis, it is not contested that a SC referral adopted after 17 July 2018 will also provide the Court with jurisdiction over this crime. ${ }^{122}$ While an Article $13(\mathrm{~b})$ referral might be

117 Milanovic, "Rome Statute Binding," 49; See Olasolo, "Principle of Legality," 306 (the purpose of this provision is that the Court cannot find criminal responsibility under the Statute for continuous crimes that occurred before the entry into force of the Statute such as enforced disappearance).

118 Milanovic, "Rome Statute Binding," 49.

119 See Ibid. p. 49; an analysis of whether the SC can set aside this provision by using its Chapter VII is undertaken in Chapter 5 of this book.

120 ICC-ASP/16/Res.5, Annex III, Understanding 1; Clearwater, "Aggression Amendments Enter into Force,", 31-63.

121 Rome Statute, Art. 121 (5)

122 On the other hand, it is contested whether declarations under Article 12 (3) will not provide the Court with jurisdiction over the crime of aggression and other amended crimes. 
retroactive, the Court's jurisdiction will only be able to cover a crime of aggression that happened after 17 July 2018. Indeed, Article 22 (1) plays a crucial role with regards to the amendments to the Rome Statute. It is thanks to this article that the Court will not be able to exercise jurisdiction over a crime that was not into force at the time of the alleged conduct - since it was not "a crime within the jurisdiction of the Court". 123

It was shown in Chapter 1 that a referral under Article 13 (b) can also trigger the Court's jurisdiction over the other amended crime(s). Article 22 (1) will play the same role with respect to these crimes as for the crime of aggression: an individual cannot be found criminally responsible for a conduct proscribed by an amendment before the entry into force of the said amendment. The distinction between aggression and other amendments is that for the latter, the amendment enters into force, and thus is within the jurisdiction of the Court, as soon as one State ratifies it. However, while Article 22 (1) ensures that the Court does not exercise jurisdiction over amended crimes before they come within the jurisdiction of the Court, the Court remains able to exercise jurisdiction over these crimes when committed after their entry into force even if, at the time they take place, the conduct was not committed by a national or in the territory of a State where the amendments were applicable law. They thus pose the same problem with the principle of legality as other crimes defined in the Rome Statute, but with a different starting date.

We have seen that the very provisions drafted to ensure that the ICC respect the principle of legality do not allow the Court to answer whether the law of the Rome Statute was applicable to the actor at the time of the impugned conduct, even if committed by a national and in the territory of a non-party State. The elephant in the room at the Rome Conference was the application of the Rome Statute in situations triggered retroactively over acts committed in the territory and by nationals of a State not party to the Statute at the time the conduct took place. In order to respect non-retroactivity, as understood in international human rights law, the law must have been in existence but

The reference to Article 12 (3) was initially part of the 'understandings' attached to the amendment, see Barriga and Kress, Travaux Préparatoires, 643-47, 79o-796; Kress and Von Holtzendorff, "The Kampala Compromise," 1213, fn 113; Milanovic, "Aggression and Legality," 177-178 (unsure); See Zimmermann and Şener, "Chemical Weapons," 443-47 (for other amended crimes). This is not the place to address this issue. For the sake of this book, we will take the negative view and thus consider that the problem posed by retroactive declarations under article 12 (3) does not apply, at least, to any new crime added to the Rome Statute after its entry into force.

123 Note that it is the date set in the activation decision of the 2017 decision that brought the crime of aggression wihtin the jurisdiciton of the Court. See ICC-ASP/16/Res.5, Annex III, Understanding 1 and 3 . 
must also have been applicable to the actor and the conduct at the time of the offence. ${ }^{124}$ While the Rome Statute constitutes a progressive development of international criminal law that might be praised in the fight against impunity, its application to any individual in the world potentially clashes with the principle of legality - especially non-retroactivity. This problem may be a result of the failure to strictly codify customary international law or of the drafters' ambition to establish a Court with universal jurisdiction. The next sections dive deep into the crucial questions whether the Rome Statute became applicable to all actors in the world at the time of its entry into force, and how the Statute interplays with the principle of legality. The two 'conceptions' adopted in this book of a referral under Article 13 (b) offer contrasting answers to these questions. Applicable to All since Its Entry into Force

The 'universal jurisdiction conception' of a referral under Article 13 (b) conceives the Rome Statute as a legislative act of the international community to establish an organ that directly exercises its jus puniendi. ${ }^{125}$ The 'type' of jurisdiction referred to here is jurisdiction to adjudicate. Further, the power to exercise this 'type' of jurisdiction is under the 'basis' of the Court's subjectmatter. The jurisdiction ratione materiae of the Court is "limited to the most serious crimes of concern to the international community as a whole". ${ }^{126}$ Indeed, a fundamental characteristic of jurisdiction to adjudicate based on the universality principle is that it is over a limited category of crimes that are of universal concern. ${ }^{127}$

According to the 'universal jurisdiction conception' the provision contained in Article 12 (2) limiting the ICC's jurisdiction to adjudicate on the basis of territoriality or nationality, absent a referral by the SC, was not required by international law but was a compromise of the States negotiating the Statute. ${ }^{128}$ Indeed, Hans-Peter Kaul qualified Article 12 (2) as "a regression from the universal jurisdiction approach which is generally recognized in customary

\footnotetext{
124 Gallant, The Principle of Legality, 23-24, 352; Milanovic, "Rome Statute Binding," 27.

125 Kress, "Immunities under International Law," 248; Olasolo, The Triggering Procedure, 18-21

126 Rome Statute, Art. 5 .

127 Randall, "Universal Jurisdiction," 785.

128 Sadat and Carden, "An Uneasy Revolution," 414; See also Scharf, "Nationals of Non-Party States," 77 .
} 
international law". ${ }^{\prime 29}$ What Kaul criticized was the limitation of the universal jurisdiction to adjudicate of the Court without being triggered by Article 13 (b). Conversely Article 13 (b) is qualified by Olasolo as the mechanism to trigger the ICC's 'dormant' universal jurisdiction to adjudicate. ${ }^{130}$

Under the 'universal jurisdiction conception' the Rome Statute's substantive criminal law is, however, neither 'dormant' nor constrained by territoriality and nationality. As previously observed, jurisdiction to adjudicate follows jurisdiction to prescribe. ${ }^{131}$ The use of Article 13 (b) sets in motion the jurisdiction of the Court to adjudicate a specific situation. The Statute, on the other hand, is in motion since its entry into force, i.e. 1 July 2002. Accordingly, the Rome Statute would be a universally applicable law since its entry into force; it is solely the Court right to adjudicate universally that is dormant.

The 'universal jurisdiction conception' conceives that jurisdiction to prescribe has been asserted at the time of the Statute's entry into force and that jurisdiction to adjudicate is lagging until the time it is activated through an $\mathrm{Ar}-$ ticle 13 (b) referral. The establishment of the ICc has prompted some scholars to affirm that the definition process at Rome was a "quasi-legislative event that produced a criminal code for the world".132 Indeed, Sadat and Carden argue that the States' delegations at the Rome Conference assumed the role of the international community's legislator. ${ }^{133}$ According to this narrative, the Rome Statute asserts prescriptive jurisdiction beyond its State parties. This overreach of the law contained in the Rome Statute is premised on the theory of universal prescriptive jurisdiction. ${ }^{134}$ That is to say, that the Rome Statute defines crimes and modes of responsibility that are applicable to any individual without geographical limits since 1 July 2002.

If the legal foundations of this 'conception' are accepted, ${ }^{135}$ the Court may declare as in Nuremberg that the Statute is "is the expression of international law existing at the time of its creation; and to that extent is itself a contribution to international law."136 Accordingly, the Rome Statute would have bound all individuals since its entry into force and would therefore always be applied

\footnotetext{
129 Kaul, "Preconditions," 6o7

130 See Olasolo, The Triggering Procedure, 39.

131 See Chapter 2, section 2.

132 Sadat, Transformation of International Law, 263.

133 Sadat and Carden, "An Uneasy Revolution," fn 35.

134 Ibid., at 381, 406-409, 412-413.

135 See Chapter 2, section 2.3 for an extensive assessment of the legal foundations and limits of the universal prescriptive jurisdiction theory.

${ }_{13} 6$ Judgment of the International Military Tribunal for the Trial of German Major War Criminals Nuremberg, 3oth September and 1st October, 1946, at 444.
} 
prospectively. This seems to be the view the ICc had of its Statute. In the Confirmation of Charges against Lubanga, Pre-Trial Chamber I described how the principle of legality operates before the ICC as follows:

there is no infringement of the principle of legality if the Chamber exercises its power to decide whether Thomas Lubanga ought to be committed for trial on the basis of written (lex scripta) pre-existing criminal norms approved by the States Parties to the Rome Statute (lex praevia), defining prohibited conduct and setting out the related sentence (lex certa), which cannot be interpreted by analogy in malam partem (lex stricta). ${ }^{137}$

The Pre-Trial Chamber considered that if the Court exercises its power on the basis of "pre-existing criminal norm approved by the States Parties to the Rome Statute" lex praevia is satisfied. On the one hand, the Chamber was suggesting that the Statute 'is effectively constitutive, as a substantive matter, of the crimes it has jurisdiction to try'.138 On the other hand, the Chamber left opaque whether the Statute approved by the State parties applies worldwide since its entry into force or only with respect to their territories and nationals.

While the Lubanga's take on the principle of legality does not settle the question whether the substantive criminal provisions of the Statute are applicable to all since its entry into force, further practice of the Court in its initial years leaned on this direction. In this respect, it must be noted that the ICC has never distinguished the applicability of the criminal norms contained in the Rome Statute in situations arising under a retroactive Article 13 (b) referral from situations where the accused, at the time of the conduct, was a national or had committed the alleged crime in the territory of a State party to the Statute. ${ }^{139}$ In fact, the same Pre-Trial Chamber I as in Lubanga was not hesitant to use a mode of liability - joint commission through another person - that is unique to the ICC for crimes committed in a territory and by nationals of a nonparty State. ${ }^{140}$ In Decision on the Confirmation of Charges against Katanga and

137 Prosecutor v. Lubanga, Case No. ICC-o1/o4-o1/o6, Decision on the Confirmation of Charges (Jan. 29, 2007), par. 303 .

138 O'Keefe, International Criminal Law, 54.

139 However, see Prosecutor v Ntaganda, Case No. ICC-o1/04-02/o6, Second decision on the Defence's challenge to the jurisdiction of the Court in respect of Counts 6 and 9 (Jan. 4, 2017), par. 35 , fn 74 .

140 Few domestic systems recognize this mode of liability, see Prosecutor v. Katanga and Ngudjolo, Case No. ICC-o1/04-01/o7-717, Decision on the Confirmation of Charges (Sept. 30, 2008), par. 504 . 
Ngudjolo, Pre-Trial Chamber I when faced with the challenge that the mode of liability used by the prosecution was not part of customary international law responded as follows: "since the Rome Statute expressly provides for this specific mode of liability, the question as to whether customary law admits or discards the 'joint commission through another person' is not relevant for this Court."141 This finding is acceptable if only applied to conduct that occurred in a territory or were committed by nationals of a State that had ratified the Statute, as it was the case for Katanga and Ngudjolo. However, Pre-Trial Chamber I also used 'joint commission through another person' in situations triggered under Article 13 (b) as a mode of liability for crimes that occurred before the referral. Indeed, without questioning the applicability of this allegedly noncustomary mode of liability when exercising jurisdiction under a retroactive Article 13 (b) referral, Pre-Trial Chamber I confirmed that it applied to OmarAl-Bashir, Muammar Gaddafi, Saif Gaddafi and Abdullah Al-Senussi. ${ }^{142}$ Given that the Chamber knew the origin of this mode of liability, and repetitively applied it for charges emerging from a retroactive referral, we can presume that the ICC was thereby confirming that it considered its Statute applicable to all since its entry into force.

If the Rome Statute bound all individuals since its entry into force, then it is never applied retroactively. In situations where the jurisdiction of the Court is triggered in relation to a date before the referral under Article 13 (b), the international community essentially uses a mechanism for the prosecution of crimes already the subject of individual criminal responsibility. ${ }^{143}$ Hence, under the 'universal jurisdiction conception' no conflict of norms between retroactive referrals and nullum crimen sine lege praevia exists. The status of an apparent conflict of norms is not even reached. Article 13 (b) Rome Statute is seen as simply confirming the right of the international community to universally prosecute crimes that it had criminalized since 2002.

While the Court early case law on the principle of legality evinces that it had adopted the 'universal jurisdiction conception', it is important to stress that such theory is only accepted by a minority of scholars. It may indeed be contested that the States adopting the Rome Statute, hence prompting its entry into force, have no authority to prescribe new criminal law for the rest of

\footnotetext{
141 Ibid., par. 508.

142 Decision to Issue an Arrest Warrant against Al-Bashir; Prosecutor v. Gaddafi, Gaddafi and Al-Senussi, Case No. ICC-o1/11-01/11-1, Decision on the "Prosecutor's Application Pursuant to Article 58 as to Muammar Mohammed Abu Minyar Gaddafi, Saif Al-Islam Gaddafi and Abdullah Al Senussi" (June 27, 2011), par. 71.

143 Prosecutor v. Delalic et al., Case No. IT-96-21-A, Judgment (Feb. 20, 2001), par. 178.
} 
the world unless this law reaches the status of customary international law. Conversely, the 'Chapter VII conception' claims that the SC can have such authority.

\section{Chapter VII Conception - Refers the Situation since ...}

The 'Chapter VII conception' of a referral under Article 13 (b) conceives the Rome Statute simply as a multilateral treaty. The Court's jurisdictional bases are territoriality or active nationality, as provided for by Article 12 (2) Rome Statute. And, indeed, these are the two traditional heads of prescriptive jurisdiction of States. States that ratified the Rome Statute delegated their territorial and active nationality jurisdiction over genocide, crimes against humanity and war crimes to the ICC. ${ }^{144}$ Similarly, those that ratified the amendments delegated their territorial and active nationality jurisdiction over the crimes covered by the amendments. As a multilateral treaty, the Rome Statute binds its State parties only. ${ }^{145}$ Thus, the Statute is the applicable law only for its State parties.

Article 13 (b) states that the ICC "may exercise its jurisdiction with respect to a crime referred to in Article 5 " if a situation "is referred to the Prosecutor by the Security Council acting under Chapter VII of the Charter of the United Nations". The exercise of jurisdiction explicitly referred to in Article 13 (b) is jurisdiction to adjudicate allegations of crimes listed in Article 5 of the Rome Statute. As O'Keefe has put it, the application of criminal law by a Court "is simply the exercise or actualization of prescription."146 Thus, when the ICC adjudicates allegations of crimes it actualizes the prescription contained in the Rome Statute. Until the time of the referral, the Rome Statute consists primarily of an exercise of jurisdiction to prescribe by its State parties over their nationals and territory. The Rome Statute becomes applicable law outside of these confines when the SC adopts a resolution referring a situation to the ICC under Chapter viI. In other words, jurisdiction to prescribe and to adjudicate is asserted concomitantly by the SC at the time of the referral.

Since the Statute only becomes applicable law for the nationals and territories concerned at the time of the Article 13(b) referral, a retroactive referral

\footnotetext{
144 See Akande, "Nationals of Non-Parties," 618; O'Keefe, "The United States and the ICC," 343-344.

145 Prosecutor v Ntaganda, Case No. ICC-o1/04-02/o6, Second decision on the Defence's challenge to the jurisdiction of the Court in respect of Counts 6 and 9 (Jan. 4, 2017), par. 35

146 O’Keefe, "Universal Jurisdiction," 737.
} 
provides not only retroactive adjudicative jurisdiction but also constitutes retroactive prescription. It is certainly recognized that international law as much as national law is a relevant source of law for the criminalization of conduct. ${ }^{147}$ However, for international law to be a relevant source it must have been applicable to the person at the time of the relevant act. The 'Chapter viI conception' of a referral under Article 13 (b) makes the Rome Statute's substantive criminal provisions applicable to the accused when the SC resolution is adopted and not before. For the acts already criminalized under customary international law before the referral the non-retroactivity prohibition is not infringed; the individual is punished for having committed a crime that was criminalized qua customary international law and within the jurisdiction of the ICC. ${ }^{148}$ For conduct that were solely criminal under the Rome Statute, on the other hand, the referral retroactively provides for their criminalization. Hence, the individual is accused of an act that did not constitute a penal offence under applicable national or international law when it was committed. Prima facie, the prohibition on non-retroactivity appears to be disregarded in such circumstances.

In the following subsections we will list the various ways the ICC can deal with the principle of legality when it exercises jurisdiction on the basis of a retroactive referral under Article 13 (b). The first sub-section will show that the Court may decide to read down the principle of legality as a principle of justice. However, adopting such a strategy is in the opinion of this author not in conformity with international law since non-retroactivity is a norm enshrined in customary international human rights law. Moreover, it is not clear whether the SC has the power to infringe the prohibition on non-retroactivity or to say the least had the intention to refer a situation to an institution that would infringe human rights law. The next sub-section will show that the SC is presumed to have intended that the ICC would respect the principle of legality. The following sub-section will try to establishing the statutory basis upon which the Court's jurisdiction may be challenged by an accused claiming that the application of a Statutory criminal provision infringes their right not to be held criminally responsible for conduct that was not a crime at the time it was committed. The two last subsections will describe how the Court may exercise its jurisdiction in respect of nullum crimen sine lege praevia as contained in customary international human rights law.

It must be emphasized that the potential clash between retroactive jurisdiction and non-retroactivity of criminal prohibition does not only exist in

147 See section 3 of this chapter.

148 Grover, Interpreting Crimes, 252. 
situations referred under Article 13(b) Rome Statute. The clash can also occur in situations where the Court exercises retroactive jurisdiction on the basis of an Article 12 (3) declaration of acceptance. While the latter jurisdiction does not involve the powers and limits of the SC, it nevertheless involves the power of the ICC to infringe customary international human rights law. In this respect, one should bear in mind that the drafters of the Rome Statute inserted a clause which states that international human rights law govern the whole exercise of ICC's jurisdiction. Moreover, as described above, the 'common intention' of the Rome Statute's drafters was indeed that the ICC should abide by the highest standard of legality.

\subsection{By Hook or By Crook-A Principle of Justice}

From a cursory reading of the list of crimes in the Statute, most are established in customary international law. The substance of genocide, crimes against humanity and war crimes as contained in the Rome Statute is prima facie consistent with the essence of these crimes in customary international law. ${ }^{149}$

To apply the Statute's substantive criminal provisions in their entirety and entitle challenges to the ICC's retroactive application of criminal law solely on the bases of Articles 22 and 24 as they currently stand would clash with the principle of legality, unless we read down the status and scope of the latter. Despite the alleged failure of the Rome Statute's drafters to codify customary international law, the drafters made sure to attune the crimes contained in the Statute to the status of "the most serious crimes of concern to the international community as a whole." If one applies nonretroactivity as a principle of justice, the gravity of the crimes within the Rome Statute would make it unjust to see a person accused of such acts go unpunished.

The starting point to held that the principle of legality must be read down when faced with the most serious crimes of concern to the international community is the Nuremberg judgment. In obiter dictum the Nuremberg Tribunal addressed the issue of nullum crimen sine lege, stating that it was not strictly bound by this principle. ${ }^{150}$ According to the Tribunal, "nullum crimen sine lege is not a limitation of sovereignty, but is in general a principle of justice."151

\footnotetext{
149 Schabas, An Introduction, 92.

150 Nuremberg Judgment, at 219; See generally Gallant, The Principle of Legality, 112-114.

151 Nuremberg Judgment, at 219; even more radically, Dissenting Opinion of Judge Rolling, Tokyo Judgment, Vol, II, at 1059 (nullum crimen sine lege "is not a principle of justice but a rule of policy"; the same reasoning was also applied in United States of America v. Josef Altstoetter et al. (Justice) 14 Annual Digest 278 (1948)).
} 
How can we apply nullum crimen sine lege in the terms of a principle of justice? The Tribunal explained why it was not unjust to condemn the defendants for crimes against peace even though at the material time it was not properly criminally sanctioned:

To assert that it is unjust to punish those who in defiance of treaties and assurances have attacked neighboring states without warning is obviously untrue for in such circumstances the attacker must know that he is doing wrong, and so far from it being unjust to punish him, it would be unjust if his wrong were allowed to go unpunished. ${ }^{152}$

In the same fashion as Kelsen proposed, the Nuremberg Tribunal balanced retroactive application of criminal law and impunity of perpetrators of atrocities. ${ }^{153}$ The moral dilemma is whether punishing individuals for acts that were not crimes when committed is a greater or lesser breach of justice than to leave the accused unpunished. ${ }^{154}$ At Nuremberg, nullum crimen sine lege praevia was trumped by the need to ensure substantive justice. ${ }^{155}$ Substantive justice aims to punish acts that harm society deeply and which are regarded as repugnant by all members of society. ${ }^{156}$ In other words, even if there were no positive rules of international law specifically criminalizing these acts it would appear unjust to leave them unpunished. ${ }^{157}$

The Nuremberg Tribunal is not the only body that retained the principle of legality as merely a principle of justice. This reasoning has been upheld in many other international criminal cases and more specifically by the Supreme Court of Israel in Eichmann. ${ }^{158}$ More recently, the Appeals Chamber of the ICTY held in Ojdanic's Motion Challenging Jurisdiction - Joint Criminal Enterprise that nullum crimen sine lege is "first and foremost, a 'principle of justice."'159 The Appeals Chamber also noted that:

\footnotetext{
152 Nuremberg Judgment, at 219.

153 See Hans Kelsen, "Ex Post Facto Laws," 46.

154 Bassiouni, Crimes against Humanity, 70.

155 Kress, "Nulla Poena,"; Cassese, International Criminal Law, 72.

156 Cassese, International Criminal Law, p. 24-26.

157 Kelsen, "Judgment in the Nuremberg Trial," 165.

158 See also Eichmann Appeal Judgment, p. 281; Cassese also cites Peleus and Burgholz (No. 2) Cassese, International Criminal Law, 26; see also Streletz and Kessler case, Germany, Federal Court of Justice, 26 July 1994, BGHSt 40, 241 (244).

159 Prosecutor v. Milutinovic et al., Case No. IT-99-37-AR72, Decision on Dragoljub Ojdanic's Motion Challenging Jurisdiction-Joint Criminal Enterprise (May 21, 2003), par. 37.
} 
Although the immorality or appalling character of an act is not a sufficient factor to warrant its criminalization under customary international law, it may in fact play a role in that respect, insofar as it may refute any claim by the Defense that it did not know of the criminal nature of the acts. 160

Accordingly, one could opine that if the accused is capable of recognizing the criminal nature of the acts because of their abhorrent character, substantive justice requires that he or she be held accountable. The obvious immorality of an act makes a presumption of fair notice to the accused that the act was criminal in nature. ${ }^{161}$ The problem with such view is nonetheless identifying the content of morality and its threshold. ${ }^{162}$

The jurisdiction of the ICC is defined in the Rome Statute and the crimes coming within the jurisdiction of the Court, for which there shall be individual responsibility, are set out in Articles 5, 6, 7, 8 and 8bis. These crimes are labeled as "the most serious crimes of concern to the international community as a whole." It may be argued that the content of immorality and its threshold have been set in the Statute, and that the SC endorses this view when it refers a case to the ICc. Note that this comes extremely close to the 'universal jurisdiction conception', however, the ascertainment of when the Statute becomes applicable in relation to the accused differs. Indeed, it is acknowledged under the 'Chapter viI conception' that the exercise of jurisdiction under a retroactive 13 (b) referral constitutes a retroactive application of criminal law. Thus a clash between retroactive exercise of jurisdiction and the retroactivity ban exists. The conflict can however be avoided if the principle of legality is read down.

In addition to considering the principle of legality as merely a principle of justice, one may argue that the Statute is in accordance with nullum crimen sine lege as generally understood since the ICC cannot find the law applicable to the accused outside of the Statute. ${ }^{163}$ No new crimes can be created by the judges, indeed; Article 22 is clear on that matter, the law of the Rome Statute is binding upon the ICC. A charge can be struck down on the basis of Articles 22

160 Ibid., par. 42; See also Prosecutor v. Delalic et al., Case No. IT-96-21-T, Judgment (Nov. 16, 1998), par. 313:

161 See Van Schaack, "Crimen Sine Lege," 119.

162 Juratowitch, "Retroactive Criminal Liability," 359.

163 Heugas-Darraspen, "Article 22," 786: "La violation du principe nullum crimen n'aurait été constituée que dans l'hypothèse où le crime contre l'humanité n'aurait pas été défini dans la charte de Nuremberg mais aurait été appliqué par le juge." However, this reasoning goes for nullum crimen not for non-retroactivity which Heugas-Darraspen says is an entirely different concept. 
and 24 but not on the ground that some crimes were beyond existing customary international law. In Nuremberg it was held that "[t]he Law of the Charter is decisive, and binding upon the Tribunal."164 This view that an international tribunal has no authority in questioning the crimes enshrined in their Charter can also be read in some of the cases of the ICTY and is still supported by some scholars. ${ }^{165}$ Accordingly, if one interprets the apparently conflicting norms in these ways there is no genuine conflict between the Statute and the principle of legality.

However, it must be acknowledged that this extremely relaxed application of the principle of legality is open to significant criticism. It was most likely true at the time of the Nuremberg judgment that non-retroactivity was merely a principle of justice. However, more than half of century later nonretroactivity has changed status. Virtually all States have integrated this principle as a binding rule within their national systems. ${ }^{166}$ Most agree that it can no longer be said that non-retroactivity is merely "a general principle of justice". 167 According to Kenneth Gallant, who undertook a comprehensive study on the principle of legality, States almost unanimously recognize non-retroactivity in their constitutions, other domestic law provisions or via treaties. ${ }^{168}$

In view of the universal ratification of human rights conventions providing for the principle of legality it may be safely said that non-retroactivity has become a rule of customary international law. ${ }^{169}$ The Special Tribunal for Lebanon has gone so far as to claim "that it is warranted to hold that by now it has the status of a peremptory norm (jus cogens)".170 Theodor Meron also claims that the rule against retroactivity has reached the status of jus cogens and Kenneth Gallant recognizes that at least it is beginning to emerge as such a norm. ${ }^{171}$ If the right of the accused not to be held criminally responsible for conduct that was not a criminal offence under applicable law at the time it was committed

\footnotetext{
164 Nuremberg Judgment, at 4; same reasoning was applied in United States of America v. Josef Altstoetter et al. (Justice) 14 Annual Digest 278 (1948).

165 Prosecutor v. Tadic, Case No. IT-94-1-A, Judgment (Jul. 15, 1999), par. 296; Schabas, The UN International Criminal Tribunals, 66-67.

166 Gallant, The Principle of Legality, 3.

167 Ibid., at 3 .

168 Ibid., at 241-242.

169 Ibid., at 3; Lamb, "Nullum Crimen," 734-742.

170 Unnamed Defendant, Case No. STL-11-o1/I, Interlocutory Decision on the Applicable Law: Terrorism, Conspiracy, Homicide, Perpetration, Cumulative Charging (Feb. 16, 2011), par. 76; see also Maktouf and Demjanovic v. Bosnia and Herzegovina, Application nos. 2312/o8 and 34179/o8, ECtHR, Grand Chamber Judgment of 19 July 2013, Concurring Opinion of Judge Pinto de Albuquerque, joined by Judge Vainie, par. 45 .

171 Meron, War Crimes Law, 244; Gallant, The Principle of Legality, 316.
} 
is a customary international norm, or even better a jus cogens norm, applying it merely as a principle of justice would be an egregious violation of that norm. In reality, we will see below that Article 21 (3) Rome Statute enjoins the Court not to apply the principle of legality as mere principle of justice.

Finally violating the principle of legality under the authority of the SC power puts the legality of the latter's action in question. Judge Pal in his dissenting opinion at the Tokyo Tribunal claimed that if the crimes charged were not law at the time of their commission it could not convict the accused "for otherwise the Tribunal will not be a 'judicial tribunal' but a mere tool for the manifestation of power". ${ }^{172}$ Under the 'Chapter viI conception' a referral under Article 13 (b) to the ICC is a manifestation of the Chapter VII powers of the SC. The ICC's failure to strictly abide by nullum crimen sine lege praevia when the SC refers a situation will thus end up in a wrongly attributed jurisdictional power.

\subsection{Presumption of Respect for Human Rights in Relation to the Security Council}

Nullum crimen sine lege has become a customary international human rights norm and a general principle of law. Although its contours (written law, specificity and strict construction) are re-designed in international criminal law, its core - non-retroactivity - remains unaffected: No one shall be convicted of any act or omission that did not constitute a criminal offense under the applicable law at the time it was committed.

A resolution of the SC retroactively referring a situation to the ICC could potentially conflict with the principle of legality. Such interaction would constitute an apparent normative conflict which would trigger the application of Article 103 UN Charter. As its text makes it clear, Article 103 requires the "event of a conflict" to have effects. ${ }^{173}$ The definition of norm conflict that is to be applied is broad. ${ }^{174}$ However, SC resolutions must be construed as "producing and intending to produce effects in accordance with existing law and not in violation of it". ${ }^{175}$ Thus a strong presumption against conflict exists and calls for techniques of harmonious interpretation to be used so that the conflict does not materialize in a genuine one. ${ }^{176}$

\footnotetext{
172 United States v. Araki et al., IMTF, Dissenting Opinion of Justice Pal, at 21.

173 UN Charter, Art. 103.

174 Paulus and Leis, "Article 103," 2123.

175 Report of the Study Group of the ILC on Fragmentation of International Law par. 39.

176 Paulus and Leis, "Article 103," 2123; See Report of the Study Group of the ILC on Fragmentation of International Law, par. 37; Pauwelyn, Conflict of Norms, 240-244.
} 
Although the wording of Article 103 refers to treaties only, the dominant view is that the Charter also prevails over other sources of international law, including customary international law. ${ }^{177}$ Hence, the SC could impose obligations whereby even customary international law would be set aside. An auxiliary question - and one that will be further developed in Chapter 5 - is whether the SC could oblige the ICC to do something. For instance, could the SC oblige the ICC to breach nullum crimen sine lege praevia. Pursuant to Article 25 UN Charter and Chapter VII, the SC can impose obligations on UN Member States. These obligations, when combined with Article 103, prevail over other obligations of UN Member States. In principle the SC cannot impose obligations on international organizations such as the ICC. ${ }^{178}$ However this has not prevented the SC from requesting international organizations to cooperate with the ICTY. ${ }^{179}$ In the same vein, the ICTY also used the power vested in it under Chapter viI to issue binding orders to international organizations such as NATO or the European Community Monitoring Mission. ${ }^{180}$ It could thus be argued that the SC could order the ICC to apply all Rome Statute's substantive criminal provisions, irrespective of nullum crimen sine lege - though this is not the view of this author. ${ }^{181}$

In Chapter 2, it was demonstrated that the presumption that the SC did not intend to prescribe new criminal law can be rebutted by a referral to the ICc. This presumption applied in terms of limiting the powers of the SC versus the sovereignty of States. However, this rebutted presumption did not concern human rights. The presumption in this case is stronger; an implicit intent is not sufficient. ${ }^{182}$ The presumption in this case is that, unless it explicitly and

177 Paulus and Leis, "Article 103," 2123; Dinstein, Customary International Law and Treaties, 425.

178 Sarooshi, "Peace and Justice," 106-107; see Chapter 5 for more this question.

179 Bank, "Cooperation," 262; Prosecutor v. Milutinovic et al., Case No. IT-05-87-ARıo8bis.1, Decision on Request of the North Atlantic Treaty Organisation for Review (May 15, 2006), par. 7 .

18 o See Prosecutor v. Dario Kordic et al. ICTY, Case No. IT-95-14/2-T, Order for the Production of Documents by the European Community Monitoring Mission and its Member States (Aug. 4, 2000); Prosecutor v. Milutinovic et al., Case No. IT-05-87-AR1o8bis.1, Decision on Request of the North Atlantic Treaty Organisation for Review (May 15, 2006), par. 8; Prosecutor v. Karadzic, Case No. IT-95-5/18-T, Decision on the Accused's Motion for Binding Order (United Nations and NATO) (Feb. 11, 2011), par. 7; see also Prosecutor v. Simic et al., Case No. IT-95-9-PT, Decision on Motion for Judicial Assistance to be provided by SFOR and others (Oct. 18, 2000), par. 46-49.

181 See Scheffer, "Staying the Course," 90 - this argument will be rebutted in chapter 5 .

182 Al-Jedda v. United Kingdom, ECtHR, Grand Chamber, Judgment, App. No. 27021/o8, 7 July 2011, par. 102; Nada v. Switzerland, ECtHR, Grand Chamber, Judgment, App. No. 10593/ 08,12 September 2012, par. 172; Al-Dulimi and Montanara Management Inc. v. Switzerland, ECtHR, Grand Chamber, Judgment, App. No. 58o9/o8, 21 June 2016, par. 139-140; See 
clearly states the contrary the SC intended that the rights to non-retroactivity of the accused be respected. ${ }^{183}$

The UN Charter's framework suggests that measures of the SC are presumed to be in accordance with international human rights law. In the course of carrying out its primary responsibility of maintaining international peace and security the SC "shall act in accordance with the Purposes and Principles of the United Nations." ${ }^{184}$ Moreover, in accordance with the principle of harmonization, the UN principles and purposes, provide direction for the interpretation and application of SC resolutions. ${ }^{185}$ As Article 1 (3) UN Charter makes clear, "promoting and encouraging respect for human rights and for fundamental freedoms" is one of the purposes of the United Nations. ${ }^{186}$ Furthermore, Article 55 (c) provides that the United Nations shall promote "universal respect for, and observance of, human rights and fundamental freedoms for all", and all UN Member States pledge in Article 56, "to take joint and separate action in co-operation with the Organization" to achieve that purpose. In light of the latter provision, it becomes clear that the creation of an International Criminal Court by some UN Member States, which offers to the United Nations the possibility to use this revolutionary judicial institution in an ad hoc basis, is an act in pursuance of "universal respect for, and observance of, human rights and fundamental freedoms for all". Thus, according to the UN Charter, the SC referrals to the ICC and the undertaking of the States party to the Rome Statute to provide a forum "to guarantee lasting respect for and the enforcement of international justice" must be read in conjunction and in accordance with international human rights. ${ }^{187}$

The ECtHR has indeed tried to avoid conflicts between SC resolutions and the ECHR. in Al-Jedda v. United Kingdom, the Court found that in the absence of clear and explicit language to the contrary "there must be a presumption that the Security Council does not intend to impose any obligation on Member

also Nabil Sayadi and Patricia Vinck (authors) v. Belgium, CCPR/C/94/1472/2006, Human Rights Committee 2008, Individual opinion of Committee member Sir Nigel Rodley (concurring), p. $36-38$.

183 Ibid.

184 UN Charter, Art. 24 (2).

185 See Report of the Study Group of the ILC on Fragmentation of International Law, par. $251(9)$.

186 See also Al-Jedda, par. 102; Stromseth et al., Can Might Make Rights?, 24; Akande, "The International Court of Justice and the Security Council," 323-325.

187 Rome Statute, preamb. par. 11, 7 "Reaffirming the Purposes and Principles of the Charter of the United Nations". 
States to breach fundamental principles of human rights." ${ }^{188}$ This principle of interpretation was reiterated in Nada v. Switzerland although the presumption was rebutted due to the clear and explicit language that was used in the SC resolution. ${ }^{189}$ In Al-Dulimi. v. Switzerland, the ECtHR rearticulated the Al-Jedda presumption as being premised on the principle of systemic harmonization between the SC resolution and human rights law. 190

Although the SC referrals of the situations in Darfur and Libya were retroactive they did not clearly and explicitly provide that the ICC is to breach the rule of non-retroactivity. In SC Resolution 1593 the SC merely: "[d]ecides to refer the situation in Darfur since 1 July 2002 to the Prosecutor of the International Criminal Court."191 The Libyan referral essentially uses the same wording with a different date. ${ }^{192}$ Put simply, the resolutions respond to Article 13 (b) which states that the ICC "may exercise its jurisdiction with respect to a crime referred to in Article 5 " if a situation "is referred to the Prosecutor by the Security Council acting under Chapter viI of the Charter of the United Nations". The resolutions restrict themselves to refer the situation to the Prosecutor retroactively; they do not take any position on the applicability of nullum crimen sine lege praevia. Although the referrals imply that the Statute in its entirety could be applied, this should not preclude the possibility that the jurisdiction of the Court can be challenged on the basis of nullum crimen sine lege praevia.

Furthermore, it must be borne in mind that the SC, while establishing previous ad hoc mechanisms for the prosecution of perpetrators of international crimes, decided to abide by the principle of non-retroactivity. This was indeed the purpose of the SC when it adopted the Statute of the ICTY, including the report of the Secretary General, asserting that the Tribunal must abide by the principle of nullum crimen sine lege. ${ }^{193}$ It could be argued that in relation to the ICTR the SC took "a more expansive approach to the choice of law" and included within the tribunal's jurisdiction crimes that were potentially beyond customary international law. ${ }^{194}$ However, the ICTR judged that there were no

188 Al-Jedda v. United Kingdom, ECtHR, Grand Chamber, Judgment, App. No. 27021/o8, 7 July 2011, par. 102.

189 Nada v. Switzerland, ECtHR, Grand Chamber, Judgment, App. No. 10593/o8,12 September 2012, par. 172 .

190 Al-Dulimi and Montanara Management Inc. v. Switzerland, ECtHR, Grand Chamber, Judgment, App. No. 5809/o8, 21 June 2016, par. 139-140.

191 SC Res. 1593, par. 1.

192 SC Res. 1970, par. 4 (the situation in Libya is referred since 10 February 2011).

193 Report of the Secretary-General pursuant to paragraph 2 of Security Council resolution 8 o8 (1993), UN Doc. S/25704 (May 3, 1993), par. 34.

194 Report of the Secretary General Pursuant to Paragraph 5 of Security Council Resolution 955 (1994), UN Doc. S/1995/134 (Feb. 13, 1995), par. 12. 
infringements on nullum crimen sine lege and that the debate on the customary nature of the impugned offences "seems superfluous" since "all the offences enumerated in Article 4 of the Statute, also constituted crimes under the laws of Rwanda." 195 Furthermore, the Rwandan succession to the Geneva Conventions of 12 August 1949 on 5 May 1964 and accession to Protocols additional thereto of 1977 on 19 November 1984 were also noted by the Secretary General in a letter to the President of the SC before the adoption of the resolution creating the ICTR. ${ }^{196}$ In the same vein, when the SC established the Special Tribunal for Lebanon it decided that the tribunal's subject-matter jurisdiction would be limited to the provisions of the Lebanese Criminal Code relating to the prosecution and punishment of acts of terrorism as well as other ordinary offences against life, related to personal integrity or illicit associations. ${ }^{197}$ Presumably, this decision to only apply domestic law was due to the debate over whether terrorism is a crime under customary international law and the contours of its definition. ${ }^{198}$ This excursus in the other situations where the SC provided jurisdiction to an international or hybrid criminal tribunal shows that the non-retroactivity prohibition was never overlooked. Hence, it could be maintained that, as in the case of the ICTY, when a SC resolution retroactively refers a situation to the ICC:

the application of the principle nullum crimen sine lege [praevia] requires that the [ICC] should apply rules of international [criminal] law which are beyond any doubt part of customary law so that the problem of adherence of some but not all States to [the Rome Statute] does not arise. ${ }^{199}$

Moreover, if one recognizes that the non-retroactivity prohibition is jus cogens then the SC cannot have adopted definitions of crimes that were beyond customary international law to be applied retroactively. 200

195 See e.g Prosecutor v. Kayishema and Ruzindana, Case No. ICTR-95-1-T, Judgment (May 21, 1999), par. 156,158 .

196 Letter dated 1 October 1994 from the Secretary-General addressed to the President of the Security Council (S/1994/1125), par. 87 .

197 Special Tribunal for Lebanon Statute, Art. 2.

198 Jurdi, "The Subject-Matter Jurisdiction," 1125.

199 Report of the Secretary-General pursuant to paragraph 2 of Security Council resolution 808 (1993), UN Doc. S/25704 (May 3, 1993), par. 34.

200 Prosecutor v. Tadic, Case No. IT-94-1-A, (Jul. 15, 1999), par. 223, par. 296; See Paulus and Leis, "Article 103," 2119-2120. See also Condorelli and Villalpando, "Can the Security Council extend," 580 (it is not even a matter of being a jus cogens norm but simply a principle that the SC should not request); Orakhelashvili, "The Impact of Peremptory Norms," 59. 
One question however remains: if the ICC is to apply nullum crimen sine lege in a different manner than how its Statute provides, on which basis is it to do so? One element of the answer lies in the jurisprudence of the ad hoc tribunals which allowed defendants to make legality challenges even if the respective statutes did not incorporate the principle of legality. ${ }^{201}$ The second element which relies on one aspect of the Rome Statute that is generally overlooked in the assessment of nullum crimen sine lege in retroactive referrals over non-party States is the requirement that the Court interprets and applies its Statute in accordance with internationally recognized human rights. ${ }^{202}$

\subsection{Here Comes Super-Legality: Article 21 (3) Rome Statute}

Article 21 Rome Statute creates a hierarchy of sources to be applied by the ICC with the Statute at its summit. ${ }^{203}$ However, although the Statute seems to posit itself as a self-contained regime, ${ }^{204}$ the ICC cannot operate in a vacuum without respecting any rules of international law. There are some norms, especially in the age of human rights, which should not be violated. ${ }^{205}$ Article 21(3) reflects this reality by creating a regime of "super-legality"; ${ }^{206}$ a "substantial hierarchy of law which supersedes the formal hierarchy between sources established by Article 21(1)." 207 Article 21 (3) posits that "[t]he application and interpretation of law pursuant to [Article 21] must be consistent with internationally recognized human rights". Gilbert Bitti argues that the 'application' of the applicable law, hence the Statute, implies that the result of any of its provisions will "always have to produce a result compatible with internationally recognized human rights law, even if such an objective does not appear from the application" of the provision contained within it. ${ }^{208}$ Hence, Article

201 Milanovic, "An Odd Couple," 1151.

202 E.g. Broomhall, "Article 22," 714 (one of the first authors to note the problem retroactive referrals poses but does not raise Article 21 (3)); for others that invoked Article 21 (3), see Gallant, The Principle of Legality, 341; Milanovic, "Rome Statute Binding," 52; Bartels, "Legitimacy and ICC Jurisdiction," 141; de Souza Dias, "Retroactive Application," 65.

203 Cryer, "Royalism and the King," 390.

204 See e.g. Grover, Interpreting Crimes, 271 ("the absence of any conflict clause and the phrase 'For the purpose of this Statute' suggest that the Rome Statute was conceived of as a selfcontained regime with the definitions contained therein at the top of the legal hierarchy"); van Sliedregt, Individual Criminal Responsibility, 13; Cryer, Cryer, "Royalism and the King," 394.

205 Scheinin, "Impact on the Law of Treaties," 23-34.

206 Pellet, "Applicable Law," 1077, Powderly, "Attempted Corseting," 485.

207 Heikkilä, "Article 21," 249; Pellet, "Applicable Law," 1077.

208 Bitti, "Article 21," 303. 
21 (3) makes a renvoi to customary human rights law, thus rendering the Rome Statute not self-contained but semi-autonomous regime. ${ }^{209}$

Under Article 19 Rome Statute, the Court is required to "satisfy itself that it has jurisdiction in any case brought before it."210 Thus, the competence of the ICC to determine its jurisdiction is not only inherent (as for the ad hoc tribunals which invoked the principle of Kompetenz-kompetenz/compétence de la compétence) but explicit. ${ }^{211} \mathrm{~A}$ challenge to the jurisdiction of the Court can also be made by an accused person, a State with jurisdiction over the case on the ground that it is investigating or prosecuting the matter or has investigated or prosecuted it, and a State from which acceptance of jurisdiction is required under Article 12. ${ }^{212}$ In order to challenge the jurisdiction of the Court one has to identify the jurisdictional ground that is lacking for the Court to be vested with jurisdiction to take cognizance of the crimes involved in the accusation. ${ }^{213}$ Pre-Trial Chamber I has defined the jurisdiction of the Court as follows:

The jurisdiction of the Court is laid down in the Statute: Article 5 specifies the subject-matter of the jurisdiction of the Court, namely the crimes over which the Court has jurisdiction, sequentially defined in Articles 6, 7, and 8. Jurisdiction over persons is dealt with in Articles 12 and 26, while territorial jurisdiction is specified by Articles 12 and 13 (b), depending on the origin of the proceedings. Lastly, jurisdiction ratione temporis is defined by Article $11 .^{214}$

The Statute erects certain barriers to the exercise of the jurisdiction of the Court; ${ }^{215}$ however, as we have seen those set up in Articles 11, 22 and 24 do not prevent the Court from exercising jurisdiction on the basis of a jurisdiction

209 Gallant, The Principle of Legality, 332.

210 Prosecutor v. Lubanga, Case No. ICC-o1/04-01/o6 (OA4), Judgment on the Appeal of Mr. Thomas Lubanga Dyilo against the Decision on the Defence Challenge to the Jurisdiction of the Court pursuant to Article 19 (2) (a) of the Statute of 3 October 2006 (Dec. 14, 2006), par. $20-24$.

211 Grover, Interpreting Crimes, 79; see Prosecutor v. Bemba, Case No. ICC-01/05-01/o8, Decision Pursuant to Article 61(7)(a) and (b) of the Rome Statute on the Charges of the Prosecutor Against Jean-Pierre Bemba Gombo (June 15, 2009), par. 23.

212 Rome Statute, Art. 19 (2).

213 Prosecutor v. Lubanga, Case No. ICC-o1/o4-o1/o6 (OA4), Judgment on the Appeal of Mr. Thomas Lubanga Dyilo against the Decision on the Defence Challenge to the Jurisdiction of the Court pursuant to Article 19 (2) (a) of the Statute of 3 October 2006 (Dec. 14, 2006), par 22.

214 Ibid., par 22.

215 Ibid., par 22 (referring to the elements listed in Article 17). 
ratione materiae or personae not established under customary international law. ${ }^{216}$ As long as the crimes are provided by the Statute and were committed after its entry into force, there seems to be little place to argue that the Court lacks jurisdiction.

Nonetheless, the Appeals Chamber of the ICC noted, in regards to Article 21 (3), that:

Article 21 (3) of the Statute makes the interpretation as well as the application of the law applicable under the Statute subject to internationally recognised human rights. It requires the exercise of the jurisdiction of the Court in accordance with internationally recognized human rights norms. [...] Human rights underpin the Statute; every aspect of it, including the exercise of the jurisdiction of the Court. Its provisions must be interpreted and more importantly applied in accordance with internationally recognized human rights $[\ldots] .^{217}$

In the Lubanga case, Article 21 (3) was used to apply the doctrine of abuse of process despite its absence from the Rome Statute and RPE. ${ }^{218}$ Article 21 (3) thus allows the Court to import norms that are not necessarily written down in its Statute and to allow for a sui generis challenge to its jurisdiction on the basis of these norms, provided that they are internationally recognized human rights.

If the prohibition of the application of retroactive criminal law is considered to be a human right norm firmly established - and this author believes it is - the Court must interpret and apply its provisions in accordance with international human rights law. In light of Article 21 (3) Rome Statute the ICC is vested with the authority to stop judicial proceedings "by declining jurisdiction, when to do otherwise would be odious with the administration of justice". 219 The ICTY had indeed considered that it "would be wholly unacceptable" for a court of law to breach the principle of legality. ${ }^{220}$ Given that the

216 Broomhall, "Article 22," 719-720.

217 Prosecutor v. Lubanga, Case No. ICC-o1/o4-01/o6 (OA4), Judgment on the Appeal of Mr. Thomas Lubanga Dyilo against the Decision on the Defence Challenge to the Jurisdiction of the Court pursuant to Article 19 (2) (a) of the Statute of 3 October 2006 (Dec. 14, 2006), par. $36-37$.

218 Ibid., par. $36-37$.

219 Ibid., par. 27; Prosecutor v. Gbagbo, Case No. ICC-o2/11-01/11, Decision on the "Corrigendum of the challenge to the jurisdiction of the International Criminal Court on the basis of Articles 12(3), 19(2), 21(3), 55 and 59 of the Rome Statute filed by the Defence for President Gbagbo (ICC-02/11-01/11-129)" (Aug. 15, 2012), par. 89.

220 Prosecutor v. Vasiljevic, Case No. IT-98-32-T, Judgment (Nov. 29, 2002), par. 19. 
exercise of jurisdiction in accordance with non-retroactivity as understood in customary human rights law is required by the Statute, a sui generis challenge to the jurisdiction of the Court is possible under that premise, and could lead the ICC to decline jurisdiction over the impugned conduct. One word of caution needs to be expressed on why this reasoning is solely applicable to a 'Chapter VII conception' of an Article 13 (b) referral - and not to a 'universal jurisdiction conception'. The ground to invoke Article 21 (3) and bring an additional nullum crimen components to the Statute's provisions on nullum crimen sine lege and non-retroactivity ratione personae does not lie on the Security Council powers. Instead, this extraordinary implant rests on the fact that the 'Chapter VII conception' recognizes that the Rome Statute became applicable law with respect the referred situation from the day of the referral only, not before. To trigger Article 21 (3) there needs to be an apparent conflict between a retroactive referral and the principle of legality - internationally recognized human rights. Given that Articles 22 and 24 do not avoid this norm conflict, it is possible to set aside the jurisdiction of the Court on the basis of a violation of nullum crimen sine lege praevia, as understood in international human rights law. This legal 'hat-trick' to avoid a conflict with the principle of legality would apply to retroactive Article 12 (3) referrals as well. Conversely, if one adopts the 'universal jurisdiction conception' there is simply no conflict - nor any lacuna - and thus no need to resort to Article 21 (3) to import an upgraded version of nullum crimen sine lege than the one enshrined in the Statute.

\subsection{Accessibility and Foreseeability - A Relaxed Application of the Principle of Legality}

In the assessment of whether a legal innovation is in conformity with the rule of non-retroactivity, the ECtHR and the ad hoc tribunals have given considerable weight to the elements of "accessibility" and "foreseeability". ${ }^{221}$ According

221 Tolstoy Miloslavsky v. United Kingdom, Court, Judgment, ECtHR, Application No. 18139/91, 13 July 1995, par. 37; S.W. v. United Kingdom, Court (Chamber), ECtHR, Judgment, Application No. 20166/92, 22 November 1995, par. 35-36; Sunday Times v. United Kingdom, Court, Judgment, ECtHR, Application No. 6538/74, 26 April 1979, par. 49. Groppera Radio AG and others v. Switzerland, Court, Judgment, ECtHR, Application No. 1089o/84, 28 March 199o, par. 68. Kononov v. Latvia, Grand Chamber, Judgment, ECtHR, Application No. 36376/o4, 17 May 2010; Kolk and Kislyiy v. Estonia, Court (Fourth Section), Decision, ECtHR, Application No. 23052/04, 17 January 2010; K.H.W. v. Germany, Court, Judgment, ECtHR, Application No. 37201/97, 22 March 2001, par. 73; Prosecutor v. Hadzihasanovic et al., Case No. IT-o1-47-AR72, Decision on Interlocutory Appeal Challenging Jurisdiction in Relation to Command Responsibility (Jul. 
to this approach, the person concerned must be able "to assess, to a degree that is reasonable in the circumstances, the consequences which a given action may entail"222 The concept of foreseeability will depend "to a considerable degree on the content of the instrument in issue, the field it is designed to cover and the number and status of those to whom it is addressed."223 Thus, "[p]ersons carrying on a professional activity must proceed with a high degree of caution when pursuing their occupation and can be expected to take special care in assessing the risks that such activity entails." ${ }^{24}$ Taking into account these sets of factors the ECtHR considers whether, with the benefit of legal advice, ${ }^{225}$ the applicant should have known that "he ran a real risk of prosecution". 226

The qualitative requirements of accessibility and foreseeability have been used to encompass various trends to justify the retroactive criminalization of certain conduct. In general, if the conduct was of such a nature that the accused could not have been innocent when committing it, its criminalization was accordingly reasonably foreseeable. The ICTY Appeals Chamber stated in Prosecutor v. Hadzihasanovic that "as to foreseeability, the conduct in question is the concrete conduct of the accused; he must be able to appreciate that the conduct is criminal in the sense generally understood, without reference to any specific provision." ${ }^{227}$ Thus, the objective elements of the crime and the requisite mens rea do not need to have been specifically provided by the law for the conduct to be punished.228

16, 2003), par. 35; Prosecutor v. Delalic et al., Case No. IT-96-21-T, Judgment (Nov. 16, 1998), par. 311; Grover, Interpreting Crimes, 171; Gallant, The Principle of Legality, 364365; Ferdinandusse, Direct Application, 237-238.

222 Cantoni v. France, Grand Chamber, Judgment, ECtHR, Application No. 17862/91, 15 November 1996, par. 35; Tolstoy Miloslavsky v. United Kingdom, Court, Judgment, ECtHR, Application No. 18139/91, 13 July 1995, par. 37; S.W. v. United Kingdom, Court (Chamber), ECtHR, Judgment, Application No. 20166/92, 22 November 1995, par. 35-36.

223 Pessino v. France, Court (Second Section), Judgment, Application No. 40403/o2, 10 October 2006, par. 33; see also Kononov v. Latvia, Grand Chamber, Judgment, ECtHR, Application No. 36376/04, 17 May 2010, par. 235.

224 Pessino v. France, Court (Second Section), Judgment, Application No. 40403/o2, 10 October 2006, par. 33 .

225 See also Pessino v. France, Court (Second Section), Judgment, Application No. 40403/o2, 10 October 2006, par. 33; see Kononov v. Latvia, Grand Chamber, Judgment, ECtHR, Application No. 36376/04, 17 May 2010, par. 235.

226 Cantoni v. France, Grand Chamber, Judgment, ECtHR, Application No. 17862/91, 15 November 1996, par. 35 .

227 Prosecutor v. Hadzihasanovic et al., Case No. IT-o1-47-AR72, Decision on Interlocutory Appeal Challenging Jurisdiction in Relation to Command Responsibility (Jul. 16, 2003), par. 35 .

228 See Swart et al., The Legacy, 223-227. 
As seen above, many advocate that the criminal nature of the crimes that are the subject matter of international criminal law do not need a specific description. ${ }^{229}$

This idea should be taken together with the claim that murder, torture, enslavement and other similar crimes are crimes that are mala in se in contrast to crimes that are mala prohibita. ${ }^{230}$ The principle of legality is thus strained to a question of whether the underlying act was criminal by its nature. ${ }^{231}$

If one uses the qualitative requirements of accessibility and foreseeability, it could be argued that any individual committing one of the crimes in the Statute could foresee that they ran a risk of prosecution. ${ }^{232}$ Indeed, the drafters of the Statute subjected all the crimes within the Statute to gravity elements and the jurisdiction of the ICC to adjudicate these crimes to gravity thresholds. The role played by the gravity element can be illustrated with the example provided in the introduction of this chapter of gender-persecution as a crime against humanity. That gender persecution is not a crime firmly established under customary international law might be a reality, but it cannot be reasonably believed that an individual did not know that he was committing an act of criminal nature when he/she severely deprived one or more persons of fundamental rights by reason of these persons' gender, as part of a widespread or systematic attack directed against a civilian population. ${ }^{233}$ Pursuant to the 'foreseeability' approach, the individual committing these crimes should have foreseen, due to their egregious nature, that this conduct was criminal. ${ }^{234}$

The 'foreseeability' approach is, however, not accepted by all. Kenneth Gallant, for instance, considers that the foreseeability requirement "may swallow the principle of legality whole." 235 The case Jorgic v. Germany where the ECtHR had to decide whether a conviction by German Courts for cultural genocide committed in Bosnia and Herzegovina violated Article 7 ECHR shows the difficulty arising from the application of the foreseeability requirement to

229 Meron, War Crimes Law, 244-248.

230 See Schabas, Unimaginable Atrocities, 34.

231 Prosecutor v. Furundzija, Case No. IT-95-17/1-T, Judgment (Dec. 10, 1998), par. 165-169; Prosecutor v. Delalic et al., Case No. IT-96-21-A, Judgment (Feb. 20, 2001), par. 178-180.

232 Schabas, An Introduction, 74.

233 For a full account of the elements of the crime of gender persecution as a crime against humanity, see Article 7 (1) (h) Crime against humanity of persecution, Elements of Crimes.

234 See Schabas, An Introduction, 74.

235 Gallant, The Principle of Legality, 364. 
international crimes. ${ }^{236}$ Article 220a of the German Criminal Code reads in the same fashion as Article 2 of the Genocide Convention, which is normally understood as excluding cultural genocide. ${ }^{237}$ However in the case of Jorgic the German Courts interpreted their genocide definition as including cultural genocide. ${ }^{238}$ The only source that could have provided Jorgic with notice of this interpretation to be adopted by the German Courts was the writings of some scholars. ${ }^{239}$ The ICTY in Krstic and the ICJ in Bosnia and Herzegovina v. Serbia had, on the other hand, struck down down this crime as not established under customary international law. ${ }^{240}$ The ECtHR, nonetheless, found that the German courts' innovative interpretation of the crime of genocide could reasonably be regarded as consistent with the essence of that offence and that with the assistance of a lawyer Jorgic could reasonably have foreseen that he risked being charged with and convicted of genocide. ${ }^{241}$ The mere fact that judges from specialized international forum disagreed on whether the crime existed casts serious doubt on the objective ascertainability of its existence. ${ }^{242}$

Evidently, the specificity of law, the value of legal certainty and the rule of strict construction are seriously challenged when foreseeability is valued more than non-retroactivity. Grover writes "there does not seem to be a sufficiently certain way to circumscribe the concept of foreseeability apart from the existence of the same criminal prohibition under applicable national law."243 The Human Rights Committee and the Inter-American Court of Human Rights have not taken up the ECtHR's qualitative requirements although they dealt with the issue of retroactivity in notable cases. ${ }^{244}$

236 Jorgic v. Germany, Grand Chamber, Judgment, ECtHR, Application No. 74613/o1, 12 July 2007, par. 27, 36, 47 .

237 E.g. Prosecutor v. Krstic, Case No. IT-98-33-T, Judgment (Aug. 2, 2001), par. 58o.

238 See Jorgic v. Germany, Grand Chamber, Judgment, ECtHR, Application No. 74613/o1, 12 July 2007, par. 27, 36, 47, 107 .

239 Van Schaack, "Crimen Sine Lege," 171-172; Booms and van der Kroon, "Inconsistent Deliberations," 167 .

240 Prosecutor v. Krstic, Case No. IT-98-33-T (Aug. 2, 2001), par. 580; Application of the Convention on the Prevention and Punishment of the Crime of Genocide (Bosnia and Herzegovina v Serbia and Montenegro) ICJ Reports 2007, par. 344.

241 Jorgic v. Germany, Grand Chamber, Judgment, ECtHR, Application No. 74613/o1, 12 July 2007, par. 113; see also the opposite result in Vasiliauskas v Lithuania, Grand Chamber, Judgment, ECtHR, Application No 35343/05, 20 October 2015 (re political genocide).

242 See van der Wilt, "Nullum Crimen," 515.

243 Grover, Interpreting Crimes, 173.

244 Juratowitch, "Retroactive Criminal Liability," 337. 
It is thus the view of this author that the accessibility and foreseeability requirements are not appropriate to deal with the issue of non-retroactivity arising from SC referrals and ad hoc declarations under Article 12 (3). There is a risk, indeed, that the accessibility and foreseeability requirements can be over-stretched to include all conduct that was mala in se but not criminalized by the law applicable at the time of commission. ${ }^{245}$ In the long run, this assessment of foreseeability is equal to assessment of whether it would be unjust to let the perpetrator of an abhorrent conduct go free as stated in the Nuremberg judgment.

\subsection{A Strict Application of Legality}

A better way to assess whether the Court while exercising jurisdiction on the basis of retroactive referrals violates the prohibition of non-retroactivity is to inquire whether the conduct constitutes a penal offence under applicable international law at the time of the alleged offence. Thus, the Court would need to confirm that the crime's definition and mode of liability under which the accused is charged is reflective of custom existing at the time of the commission. ${ }^{246}$

In addition to customary international law, the Court can look at other sources of international law (i.e. applicable treaties and general principles of law) if they entailed individual criminal responsibility at the time of the conduct in question. Article 21 (1) (b) Rome Statute opens the door for judges to look at "applicable treaties and the principles and rules of international law, including the established principles of the international law of armed conflict". ${ }^{247}$ In doing so, the individual is punished for conduct that was indeed criminal at the relevant time but by a source of law other than the Rome Statute. Hence, the retroactive referral would not clash with the rule on non-retroactivity.

Failing that the conduct was not criminalized by customary international law, treaties or general principles of international criminal law, Article 21 (1) (c) allows the Court to apply "general principles of law derived by the Court from national laws of legal systems of the world including, as appropriate,

245 Gallant, The Principle of Legality, 364-365; Grover, Interpreting Crimes, 171-173; See Schabas, An Introduction, 34 .

246 Broomhall, "Article 22," 720; Meron, "Revival," 832; Gallant, "Jurisdiction to Adjudicate and Jurisdiction to Prescribe," 826; Gallant, The Principle of Legality, 339-341; Grover, Interpreting Crimes, 262; Milanovic, "Rome Statute Binding," 51.

247 Arsanjani, "The Rome Statute," 29; Prosecutor v. Lubanga, Case No. ICC-o1/o4-o1/o6 (OA4), Judgment on the Appeal of Mr. Thomas Lubanga Dyilo against the Decision on the Defence Challenge to the Jurisdiction of the Court pursuant to Article 19 (2) (a) of the Statute of 3 October 2006 (Dec. 14, 2006), par. 34 . 
the national laws of States that would normally exercise jurisdiction over the crime."248 Thus, the Court could also look at the domestic law applicable to the conduct to see whether a crime sufficiently similar to the Rome Statute's provision existed under applicable national law. ${ }^{249}$ The ICTR's jurisdiction over 'common Article 3' and Additional Protocol II was also based on the fact that these conventions were in force at the time of the conflict and that the offences within the tribunal's jurisdiction were crimes under the laws of Rwanda..250 Hence, the offences under domestic law, which criminalize norm contained in the Geneva Convention and the Additional Protocol, were essentially reclassified as an international crime.

More controversially, if the Court finds that the underlying acts were criminalized under applicable national law, the offence can also be reclassified as an international crime. ${ }^{251}$ That 'ordinary' crimes are committed in a wider context as either crimes against humanity or genocide or in nexus with an armed conflict does not entail that an individual can believe that these acts were not criminal. ${ }^{252}$ The accused was committing a crime at the time of the commission; the additional factors required to make the domestic crime an international one are qualified as 'jurisdictional' or 'aggravating.'. 253 Thus, the principle of non-retroactivity is not necessarily offended. The core of the rule appears to be met since the act was a crime under applicable law when committed..$^{254}$

248 However, we ought to be cautious when using Article 21 (1) (b) and (c) Rome Statute. There is indeed the danger that subsidiary sources be used in contradiction with the principle of strict construction contained in Article 22(2); See Prosecutor v. Lubanga, Case No. ICC-o1/o4-01/o6-2842, Judgment pursuant to Article 74 of the Statute, Separate Opinion of Judge Adrian Fulford (Mar. 14, 2012); see also Prosecutor v. Ngudjolo, Case No. ICC-o1/ 04-02/12-4, Judgment pursuant to Article 74 of the Statute - Concurring Opinion of Judge Christine Van den Wyngaert, 18 December 2012.

249 Van Schaack, "Crimen Sine Lege," 168; Grover, Interpreting Crimes, 162; Gallant, The Principle of Legality, 131-132.

250 See Prosecutor v. Kayishema and Ruzindana, Case No. ICTR-95-1-T Judgment (May 21, 1999), par. $156,158$.

251 This technique must be distinguished from the re-characterization of charges, a procedure used at the ICC, under Regulation 55; see Prosecutor v. Katanga, Case No. ICC-o1/o4o1/o7, Jugement rendu en application de l'Article 74 du Statut, Minority Opinion of Judge Christine Van den Wyngaert (Mar. 8, 2014); On reclassification of the crime see Gallant, The Principle of Legality, 367-369, contra de Souza Dias, "Retroactive Application," 76-84.

252 United States v. von Leeb (The High Command Case); Rölling, The Law of War, 345-46; Van Schaack, "Crimen Sine Lege," 168.

253 Van Schaack, "Crimen Sine Lege," 168-169; Grover, Interpreting Crimes, 162; Gallant, The Principle of Legality 131-132.

254 Gallant, The Principle of Legality, 367; Grover, Interpreting Crimes, 183. 
However, when international crime is reclassified as an ordinary crime, the crime is not properly labeled and the stigma for committing an international crime is not recognized. ${ }^{255}$ Thus, reclassification of crimes remains a tool that, at the very least, must be circumscribed. Furthermore, in order to also respect nulla poena sine lege praevia, only the sentence applicable under national law for the underlying conduct at the time of commission should be applied. ${ }^{256}$ Therefore, to be in accordance with these two components of legality (nullum crimen and nulla poena sine lege), the crime must have existed under domestic applicable law at the time of commission and the sentence cannot be higher than the one provided for by the domestic applicable law. ${ }^{257}$

Finally, it is not clear whether every crime under the Rome Statute contains an underlying act criminalized by applicable domestic law. ${ }^{258}$ For instance, enlisting child soldiers is not a crime in every State. ${ }^{259}$ In this circumstance the reclassification of the offence would be of no avail unless the act was criminal under customary international law (which is probably the case now) or applicable treaty law providing for direct criminal liability. ${ }^{260}$ If none of this proscription was applicable at the time of the conduct, the Court must decline jurisdiction over the charge.

To sum up, despite the lack of a specific provision in the Rome Statute allowing an accused to challenge the jurisdiction on the ground that the Statute was not applicable to them - even though it was in force - retroactive referrals do not genuinely conflict with the rule of non-retroactivity. Applying Article 21 (3) as an interpretative clause gives the same result as a conflict clause; however the existence of genuine conflict is precluded since the judges are able to interpret away the apparent conflict. ${ }^{261}$ In particular, integrating nullum crimen sine lege praevia within the Rome Statute through Article 21 (3) is an example of systemic interpretation as enjoined by Article 31(3)(c) of the Vienna Convention on the Law of Treaties. Furthermore, Article 21 (3) Rome Statute also enjoins the Court to resort to Article 21 (1)(b) and (c) as possible sources under which the accused committed a crime and can if the conduct was not criminalized under any law applicable to the accused, at the time of the conduct, decline to exercise jurisdiction. ${ }^{262}$

\footnotetext{
255 Grover, Interpreting Crimes, 164; de Souza Dias, "Retroactive Application," 76-84.

256 Gallant, The Principle of Legality, 368; See also Meron, War Crimes Law, 246.

257 The latter requirement derives from nulla poena sine lege, see Gallant, The Principle of Legality, 341.

258 Gallant, The Principle of Legality, 367-368.

259 See Van Schaack, "Crimen Sine Lege," 158.

26o Gallant, The Principle of Legality, 368.

261 Pauwelyn, Conflict of Norms, 334

262 Bitti, "Article 21," 303.
} 


\section{Conclusion}

Although the Rome Statute was adopted by a non-unanimous vote, it is argued under the 'universal jurisdiction conception' that the international community decided to make it universally applicable from its entry into force. ${ }^{263}$ While it is true that the Statute speaks of 'crimes of international concern', is this sufficient to establish the authority to universally prescribe all the crimes contained in the Statute? The answer begs the question. If the Statute can be considered an act of the international community, then it has the authority and legitimacy to universally prescribe crimes of international concern. Or, is the Rome Statute assertion to be an act of the international community a false pretension? Should we refer to the 'ICC community'?

It must be acknowledged that the Rome Statute's drafters carefully selected the crimes included in Articles 6 to 8bis of the Statute and subjected them to gravity elements and thresholds. Gravity ensures, firstly, that due to its inherent gravity the conduct is universally regarded as punishable. ${ }^{264}$ Secondly, the gravity of the crime makes it a matter of such serious international concern that it cannot be left to the discretion of even the most directly concerned State. The proponents of the 'universal jurisdiction conception' claim that, for these reasons, the crimes contained in the Rome Statute were made universally applicable at the time of its entry into force. If this reasoning is accepted then the Rome Statute provisions on the Court's jurisdiction ratione temporis, nullum crimen sine lege, nulla poena sine lege and non-retroactivity ratione personae are fully consistent with the principle of legality even in situations retroactively referred under Article 13 (b).

While the 'universal jurisdiction conception' considers that the Rome Statute can be applied uniformly to all accused, regardless of whether the State(s) with primary jurisdiction had ratified the Statute, the 'Chapter VII conception' conceives that the Rome Statute becomes applicable law to a specific situation outside of the ICC's ambit but triggered under Article 13 (b) when the SC uses its extraordinary powers to target that specific territory. Under the 'Chapter VII conception', the Rome Statute becomes applicable law in the referred territory's legal order at the time of the referral, not before. There is therefore an apparent conflict between retroactive Article 13 (b) referrals and the principle of legality.

263 Sadat, Transformation of International Law, 184-185.

264 See Einarsen, The Concept of Universal Crimes, 253; United States of America v Wilhelm List et al. (Hostage), XI TWC 1241. 
It has been shown that there are three ways - if one adopts the 'Chapter VII conception' - to interpret the interaction of retroactive referrals under Article 13 (b) with the principle of legality. Firstly, if one applies non-retroactivity like in Nuremberg as a general principle of justice, a retroactive application of the 'most serious crimes of concern to the international community' would not be unjust. Thus, by reading down the status of the principle of legality, there would be no genuine conflict. While this position might be supported by those in favor of substantive justice, it fails to acknowledge that the principle of legality is now a human rights norm firmly entrenched in customary international law. Accordingly, the correct view according to this author is that the Nuremberg's balancing exercise leads to an unresolvable conflict, where nonretroactivity is breached for the sake of punishing immoral conduct.

Secondly, if one considers that non-retroactivity is a norm firmly established in customary international human rights law: one has to consider that the ICC must interpret its Statute in light of this norm. Thus, in situations where the Court exercises jurisdiction over conduct that occurred prior to a SC referral, it can only find an accused guilty if the conduct was criminal under applicable treaty law, customary international law, general principles of law or (but controversially) national law. In other words, the Court must refer to sources other than its Statute in order to resolve the conflict between its retroactive exercise of jurisdiction and the retroactivity ban.

Thirdly, a way of avoiding the apparent conflict between retroactive referrals and non-retroactivity of criminal law that is in between the two previous solutions is to assess whether the accused could have reasonably foreseen, at the relevant time, that they were committing a crime. Although some courts which consider non-retroactivity as a human right adopted the 'foreseeability' element, this element when used in the context of 'the most serious crimes of concern to the international community as a whole' risks being reduced to a simple evaluation of the gravity of the crime. Hence, it may end up being a simple application of non-retroactivity as a principle of justice under another formula. All in all, only the second way to resolve the conflict between retroactive referrals and non-retroactivity of criminal law sharply differs with the 'universal jurisdiction conception'.

Contrary to the 'universal jurisdiction conception', under the 'Chapter viI conception' selectivity appears to be part of the judicial process - accused are not treated alike but according to the law applicable to their conduct at the time. One may have concerns that the term 'selectivity' resonates too much with 'victor's justice', a term that is reminiscent of the criticisms made against the Nuremberg and Tokyo Tribunals. On the other hand, does the Rome Statute really have the legal capacity to be imposed upon any State, and more 
specifically against any accused without any accommodation to the legal order of the specific situations at stake? The legitimacy of the Court in such situations could rest on the way conflicts of norms are handled. To avoid a norm conflict between retroactive referrals and non-retroactivity by completely delinking the Rome Statute from international law risks not only resulting in another manifestation of 'victor's justice' but also reflecting the 'identity crisis' affecting international criminal law. 265

265 See Robinson, "The Identity Crisis," 925. 